\title{
Perspectives on the Future of Ice Nucleation Research: Research Needs and Unanswered Questions Identified from Two International Workshops
}

\author{
Ivan Coluzza $^{1}$, Jessie Creamean ${ }^{2,3}$ (D), Michel J. Rossi 4 (D), Heike Wex ${ }^{5}$ (D), \\ Peter Aaron Alpert 6,7 (DD, Valentino Bianco ${ }^{1}$, Yvonne Boose ${ }^{8}$, Christoph Dellago ${ }^{1}$, \\ Laura Felgitsch ${ }^{9}$, Janine Fröhlich-Nowoisky ${ }^{10}$, Hartmut Herrmann ${ }^{5}$, Swetlana Jungblut ${ }^{1}$, \\ Zamin A. Kanji ${ }^{8}$ (D), Georg Menzl ${ }^{1}$, Bruce Moffett ${ }^{11}$, Clemens Moritz ${ }^{1}$, Anke Mutzel ${ }^{5}$, \\ Ulrich Pöschl ${ }^{10}$, Michael Schauperl ${ }^{12}$, Jan Scheel ${ }^{10}$, Emiliano Stopelli ${ }^{13}$, Frank Stratmann ${ }^{5}$, \\ Hinrich Grothe ${ }^{9, *}$ (D) and David G. Schmale III $9,14, *$ (iD
}

1 Faculty of Physics, University of Vienna, Boltzmanngasse 5, 1090 Wien, Austria; ivan.coluzza@univie.ac.at (I.C.); valentino.bianco@univie.ac.at (V.B.); Christoph.Dellago@univie.ac.at (C.D.); swetlana.jungblut@univie.ac.at (S.J.); georg.menzl@univie.ac.at (G.M.); clemens.moritz@univie.ac.at (C.M.)

2 Earth System Research Laboratory, National Oceanic and Atmospheric Administration, R/PSD, 325 Broadway, Boulder, CO 80305, USA; jessie.creamean@noaa.gov

3 Cooperative Institute for Research in Environmental Sciences, University of Colorado, UCB 216, Boulder, CO 80309, USA

4 Paul Scherrer Institut, Laboratory of Atmospheric Chemistry, CH-5232 Villigen PSI, Switzerland; michel.rossi@psi.ch

5 Leibniz Institute for Tropospheric Research, Permoserstr. 15, D-04318 Leipzig, Germany; wex@tropos.de (H.W.); herrmann@tropos.de (H.H.); mutzel@tropos.de (A.M.); stratmann@tropos.de (F.S.)

6 University Lyon, Université Claude Bernard Lyon 1, CNRS, UMR 5256, IRCELYON, Institut de Recherches sur la Catalyse et L'environnement de Lyon, 2 avenue Albert Einstein, F-69626 Villeurbanne, France; peter.alpert@psi.ch

7 Paul Scherrer Institut, Environmental Chemistry, CH-5232 Villigen PSI, Switzerland

8 Institute for Atmospheric and Climate Science, ETH Zürich, Universitätstrasse 16, CH-8092 Zürich, Switzerland; yvonne.boose@kit.edu (Y.B.); zamin.kanji@env.ethz.ch (Z.A.K.)

9 Institute of Materials Chemistry (E165), Technische Universität Wien, Getreidemarkt 9/BC/1, A-1060 Wien, Austria; laura.felgitsch@tuwien.ac.at

10 Multiphase Chemistry Department, Max Planck Institute for Chemistry, Hahn-Meitner Weg 1, D-55128 Mainz, Germany; j.frohlich@mpic.de (J.F.-N.); u.poschl@mpic.de (U.P.); j.scheel@mpic.de (J.S.)

11 Ocean Lab, Fishguard, Pembrokeshire SA65 9HH UK; b.f.moffett@gmail.com

12 Institut für Allgemeine, Anorganische und Theoretische Chemie, Centrum für Chemie und Biomedizin, Innrain 80-82, Innsbruck, Austria; schauperl.michael@gmail.com

13 Environmental Geosciences, Department of Environmental Sciences, University of Basel, Bernoullistrasse 30, CH-4056 Basel, Switzerland; emiliano.stopelli@unibas.ch

14 Department of Plant Pathology, Physiology, and Weed Science, Virginia Tech, 420 Ag Quad Lane, Latham 413, Blacksburg, VA 24060-0390, USA

* Correspondence: dschmale@vt.edu (D.G.S.); grothe@tuwien.ac.at (H.G.); Tel.: +1-540-231-6943 (D.G.S.); +43-1-58801-165122 (H.G.)

Received: 20 June 2017; Accepted: 20 July 2017; Published: 28 July 2017

\begin{abstract}
There has been increasing interest in ice nucleation research in the last decade. To identify important gaps in our knowledge of ice nucleation processes and their impacts, two international workshops on ice nucleation were held in Vienna, Austria in 2015 and 2016. Experts from these workshops identified the following research needs: (1) uncovering the molecular identity of active sites for ice nucleation; (2) the importance of modeling for the understanding of heterogeneous ice nucleation; (3) identifying and quantifying contributions of biological ice nuclei from natural and managed environments; (4) examining the role of aging in ice nuclei; (5) conducting targeted sampling campaigns in clouds; and (6) designing lab and field experiments to increase our understanding of
\end{abstract}


the role of ice-nucleating particles in the atmosphere. Interdisciplinary teams of scientists should work together to establish and maintain a common, unified language for ice nucleation research. A number of commercial applications benefit from ice nucleation research, including the production of artificial snow, the freezing and preservation of water-containing food products, and the potential modulation of weather. Additional work is needed to increase our understanding of ice nucleation processes and potential impacts on precipitation, water availability, climate change, crop health, and feedback cycles.

Keywords: water; ice nucleation; precipitation; INP; IN; INM; crystal; cloud glaciation; nucleation sites; aging

\section{Background and Motivation}

The formation of ice in clouds occurs by homogeneous and heterogeneous ice nucleation [1]. Droplets in clouds nucleate on aerosol particles, some of which freeze to form ice crystals. A variety of ice-nucleating particles have been identified in clouds and implicated in precipitation, including soot, mineral dust, pollen, bacteria, and fungi [2,3]. There has been a resurgence in ice nucleation research within the last decade [4], largely because of the pressing need to understand the impact of aerosols on precipitation and climate. A recent AMS monograph on the topic has produced reviews in 11 chapters, covering topics including cirrus and contrail ice, ice fog, mixed-phase clouds, formation of precipitation, secondary ice production, and measurement methods [5]. In addition to atmospheric issues, there are a number of important commercial applications for ice nucleation research, including the production of artificial snow [6], the freezing and preservation of water-containing food products [7], the freeze protection of infrastructure [8], and the potential modulation of weather [9]. Many of these fields need new research to fill important gaps in fundamental knowledge of ice nucleation processes and their impacts.

Here, we identify and discuss six major research needs and unanswered research questions in atmospheric ice nucleation research, many of which have received only cursory attention in the past. The major research topics in need of further work came out of the two international workshops held in Vienna in 2015 and 2016, and are briefly outlined in Section 2 through 7 of this manuscript. The workshops were held 11-12 April, 2015 and 16-17 April, 2016 at the Italian Cultural Institute in Vienna, Austria. The workshop programs were designed around breakout discussions, where workshop attendees had engaging conversations with presenters immediately following each of the sessions. Some discussions concerned fundamental questions about ice nucleation, while others discussed engaging stakeholders with various topics presented throughout the workshop. Many of the attendees of the workshops were early career scientists actively engaged in ice nucleation research, introducing new ideas and concepts and the current state-of-the-art in ice nucleation. At different points throughout the 2015 workshop, speakers and other workshop attendees formed small groups to develop a list of hot topics and research priorities. At the 2016 workshop, this list was reduced after additional discussion to six topics, which are presented here as the basis of this manuscript.

This manuscript is not meant to be review paper, a monograph, or an overview article. Rather, this document represents a commentary on research needs and unanswered questions at the frontier of ice nucleation research. There are many unanswered questions which we hope to 'nucleate' by interacting closely as a growing interdisciplinary scientific community.

\section{Uncovering the Molecular Identity of Active Sites for Heterogeneous Ice Nucleation}

The overall goal of this section is to highlight the need to obtain a fundamental understanding of ice nucleation processes on a molecular level to understand and control ice nucleation events. Nucleation is a kinetic process, where the activation barrier determines how fast, and at what 
temperature nucleation occurs. Pruppacher and Klett [1] have proposed criteria to define an ice nucleation particle including size, (in)solubility, solid surface, crystallographic structure similar to ice, and structural heterogeneities and imperfections (discussed in [10]). Surface composition and specific molecular features are likely to be important, which differ depending on physical state, surface structure, distribution of functional groups and environmental chemistry of active sites. In situ and non-invasive techniques should be used to address the role of structural parameters of ice-nucleating substrates, either to characterize a solid interface (gas-condensed phase) or the dynamic structure of a solution into which the ice nuclei are immersed [11,12].

Future work under Section 2 should address the following three main questions:

Question 2.1: What are the relevant surface features of ice-nucleating interfaces? What is the molecular basis for the hydrophilic or hydrophobic character of an interface?

Question 2.2: What are the observable physical-chemical properties of the interface in molecular composition, surface functional groups, and/or structural features of confirmed ice nucleation species?

Question 2.3: Which techniques should be applied or developed to experimentally validate and interpret interfacial properties of ice nucleation at a molecular level with the goal to afford predictive capabilities as well as control of ice nucleation?

For Question 2.1, new information on surface features are needed in terms of spatial extent (dimension of interfacial regions enabling ice nucleation), surface crystallographic structure, and chemical composition necessary for a high ice nucleation rate at modest water vapor supersaturation. Different combinations of functional groups/structures at the interface may give rise to a different degree of hydrophilic or hydrophobic interaction ([13] Figure 1). Two important concepts related to Question 2.1 concern contact angle and a common theoretical base for the four classical freezing mechanisms (deposition ice nucleation and condensation, immersion and contact freezing) proposed by Pruppacher and Klett [1]. A contact angle, which can be obtained using the sessile drop technique, is a macroscopic concept that is not reconcilable with the intended molecular view of the interface.

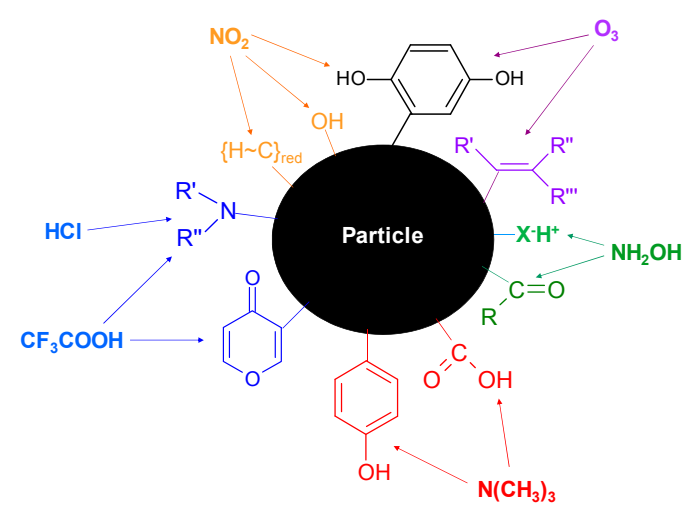

Figure 1. The interfacial titration scheme of surface functional groups of a "particle" wherein reactive molecules "interrogate" the chemical properties of the interface such as reducing, oxidizing, acidic, and basic properties using the oxidizers $\mathrm{O}_{3}, \mathrm{NO}_{2}$, the reducing molecule $\mathrm{NH}_{2} \mathrm{OH}$, the base trimethylamine $\left(\mathrm{N}\left(\mathrm{CH}_{3}\right)_{3}\right)$ and the acids $\mathrm{CF}_{3} \mathrm{COOH}$ and $\mathrm{HCl}$, respectively, as probe gases. The measurement takes place in a low-pressure flow reactor where the uptake of each probe gas is monitored in the presence of the particles by sequentially recording the irreversible loss (disappearance) of gas. The result is reported in terms of (fractions of) molecular monolayers of consumed (lost) molecules as a function of the type and chemical reactivity of the probe gas.

The four classical freezing mechanisms (deposition ice nucleation and condensation, immersion and contact freezing) may coalesce into one if a fundamental freezing mechanism could be formulated and a kinetic rate law be determined. Under the condition that the distinction between deposition and condensation freezing may be maintained in the future, these two freezing modes rely on mass 
transport of water vapor across the gas phase which has little to do with the intrinsic freezing mechanism. In contrast, immersion and contact freezing may depend on the reversible formation of adsorbed water clusters or aggregates of sufficient similarity to ice within condensed (liquid) water, identifying the freezing process as a fundamental singular or stochastic event provided that a sufficient equilibrium concentration or the viability of at least one "ice embryo" in contact with liquid water is ascertained. Once the phase transition has been triggered at one location of the heterogeneous ice nucleus propagation may be fast and wave-like because no mass transport is involved. However, Wex et al. [14] have already proposed to remove the classification between immersion and condensation freezing in a heterogeneous molecular system based on a series of experiments using the clay kaolinites as an ice-nucleating species, and Vali et al. [15] discuss the differences between ice nucleation modes further. Additionally, Marcolli [16] hypothesizes that deposition nucleation might rather be identified by pore condensation followed by freezing in voids and cavities in aggregated primary particles occurring at relative humidities (with respect to water) below 100\% due to the inverse Kelvin effect. This is observed in confined systems such as cylindrical pores, capillaries or interstices of two touching spheres when water interacts with wettable surfaces which leads to a concave meniscus and to a decrease of the equilibrium water vapor pressure owing to attractive forces between the average water molecule and the polar interface $[17,18]$. This effect may lower the water vapor pressure down to 30 or $40 \%$ of its equilibrium value, and is the opposite of the Kelvin effect observed for free-standing or suspended water droplets or non-wettable systems such as $\mathrm{Hg} / \mathrm{SiO}_{2}$ interfaces leading to a convex meniscus associated with an increase in vapor pressure. Hiranuma et al. [19] underlines the identical ice-nucleating efficiency for condensation and immersion freezing experiments suggesting the formal identity of both mechanisms for aerosolized microcrystalline cellulose fibers obtained in a cloud expansion chamber.

In the interest of progress, we propose to search for freezing mechanisms in terms of elementary chemical processes. One would expect that deposition and condensation freezing may be controlled by an intrinsic stochastic freezing process as a rate-limiting step, the mass-transport across the gas phase notwithstanding. However, there is another potential and fundamentally different view of ice nucleation from supercooled aqueous solutions in terms of immersion or contact freezing, namely that the process may be viewed as a spontaneous (=barrierless) autocatalytic process once a single viable ice embryo is "born" out of a stochastic process. In terms of which formalism to choose, there is a real divide between a thermodynamic approach (viable embryo leading to larger aggregates in reversible processes) or a kinetic/stochastic approach in which a specific encounter or collision complex formed in the condensed phase and having a short lifetime may be sufficient to trigger the phase transition across the condensed phase. A first step of simplification may be to divide the four freezing "mechanisms" into two, one (deposition nucleation and condensation freezing) that forms the nucleation transient (critical nucleus or embryo) from the gas phase side, the other (immersion and contact freezing) forming the freezing precursor in the condensed phase (supercooled water).

Regarding Question 2.2, a re-interpretation of observable physical-chemical properties of interfaces is needed in the context of ice nucleation. Empirical data following classical physical chemistry have been gathered in the past including contact angles (sessile drop technique), surface tensions (Wilhelmy plates, balances and other related methods), and grain sizes in aqueous suspensions with time (Ostwald ripening corresponding to the trend towards thermodynamic stability, following Ostwald's step rule). Many examples of pertinent laboratory research and observational evidence on ice nucleation may be given, therefore in the interest of brevity just a few are given here [20-24]. However, it has not yet been determined which quantitative formalism should be developed in order to take the relevant competing molecular interactions into account because the latter are not yet known with certainty. A surface thermodynamic approach based on a free energy balance split into contributions between molecule-molecule and molecule-interface interactions may be feasible wherein the surface enthalpies and surface entropies (2-D for surface, standard 3-D for gas phase) are amenable to molecular interpretation using statistical thermodynamic approaches [25]. 
For Question 2.3, this question may ultimately lead to enable some control of ice nucleation activities or rates of a particular ice-nucleating particle in the future. This is indeed very challenging and should be realized in conjunction with numerical modeling calculations addressing the function or action of the different surface functional groups on ice formation. Surface techniques mostly sensitive to interfacial chemical composition need to be explored to validate and interpret interfacial properties of ice nucleation at a molecular level. High-Energy Electron-spectroscopic and X-ray techniques based on photoelectron detection have a penetration depth of 1-2 $\mathrm{nm}[11,12,26,27]$. Chemical titration may be conducted using suitable gas probes for the interrogation of the presence of several types of functional groups at the interface [13]. For instance, the titration using trimethylamine $\left(\mathrm{N}\left(\mathrm{CH}_{3}\right)_{3}\right)$ probing acidic functional groups or trifluoroacetic acid $\left(\mathrm{CF}_{3} \mathrm{COOH}\right)$ probing basic functional groups results in the quantitative determination of the surface composition of the investigated condensed phase at the penetration depth of a single molecular monolayer (Figure 1). Low-energy (UV/Vis and IR, Raman) spectroscopic techniques based on photon detection have larger penetration depths, usually between 4-100 molecular monolayers ( 1 to $50 \mathrm{~nm}$ ) depending on the optical arrangement and selection rules. Of particular interest are recent experiments exploring the degree of molecular order in liquid solutions or in melting ices using advanced (non-invasive) optical methods such as laser-based non-linear second harmonic sum frequency generation (SFG) schemes that reveal molecular ordering at temperatures significantly higher than the formal freezing point of the aqueous solution [28,29]. Probing the properties of reactive and non-reactive systems at the liquid or disordered ice interface (quasi-liquid layer forming the interface between the gas and the condensed (ice) phase) is another promising technique that has not often been applied in the last 20 years or so when you restrict your view onto those studies that are sensitive to only a few molecular layers. Two examples are the measurement of the reaction kinetics and products of $\mathrm{ClONO}_{2}$ on pure $\mathrm{H}_{2} \mathrm{O}$ ice resulting in $\mathrm{HOCl}$ using SFG techniques [11]. The second example is the examination of the properties of $\mathrm{HCl}$ adsorbed on pure $\mathrm{H}_{2} \mathrm{O}$ ice using spectral ellipsometry [12]. Both studies were conducted at stratospherically relevant temperatures in the range $180-210 \mathrm{~K}$, and revealed interfacial details at an unprecedented level and sensitivity (on the order of less than $1 \%$ of a molecular monolayer), because both methods are highly sensitive to the first few molecular monolayers owing to strict optical selection rules. These in situ and non-invasive techniques address the role of structural parameters of ice nuclei, either to characterize a solid interface (gas-condensed phase) or the dynamic structure of a solution into which the ice nuclei are immersed.

\section{The Importance of Molecular Modeling for the Understanding of Heterogeneous Ice Nucleation}

A molecular understanding of ice nucleation can be obtained by computer simulations (Figure 2) [30-35]. Ice nucleation activity is influenced by several independent molecular properties, including surface hydrophobicity [32,36,37], surface morphology [38], and local electric fields [39-41]. The widespread notion that ice nucleation agents have surfaces similar to the surfaces of ice has recently been challenged [42], and even amorphous surfaces may act as good ice nuclei [43]. A comparison of experimental observations and computer simulation of nucleation of ice on feldspar showed that ice has higher nucleation rates at the surface regions with a larger number of defects [44]. Consequently, ice nucleation needs to be investigated as a function of different molecular properties, such as water-substrate interactions and surface morphologies. 

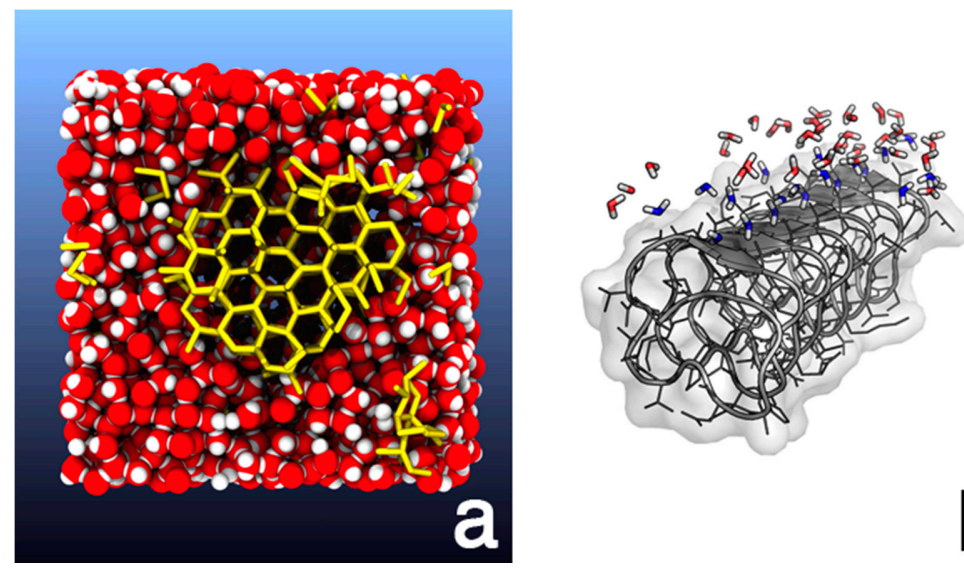

b

Figure 2. Computer simulations of pure water represent a viable starting point for studies of heterogeneous ice nucleation. (a) Computer generated ice nucleus using the TIP4P/ice water model [45]. The nucleation was obtained in conditions of homogeneous nucleation. Figure reprinted from S. Jungblut and C. Dellago, "Pathways to self-organization: Crystallization via nucleation and growth", Eur. Phys. J. E 39, 77 (2016), with kind permission of The European Physical Journal (original picture courtesy of Philipp Geiger). (b) Computer simulation of beetle antifreeze protein [46] with representative water molecules close to the ice binding region. Water at the surface of the protein (grey) show slower dynamics (blue) similar as water at an ice surface, whereas red water molecules show dynamics similar as liquid water.

Most of the recently published computational studies of heterogeneous ice nucleation used the monoatomic coarse grained $\mathrm{mW}$ water model [47,48]. The fast dynamics of this simple water model and its numerical efficiency are the main reasons why current brute force simulation methods can be applied to the ice nucleation problem. Computational nucleation studies with more accurate but computationally demanding all atom water models, like TIP4P/2005 [49] and TIP4P-Ice [45], are challenging because of the shorter accessible simulations times. Their dynamics is intrinsically slower than that of coarse grained models. Nevertheless, the explicit description of hydrogens and the explicit inclusion of long-range electrostatic interactions, often neglected in coarse grained models, can be crucial to obtain correct simulation results for different phases [50]. An even more accurate and very general way to model the interaction of water molecules with each other and with different substrates is by calculating forces and energies from first principles electronic structure calculations, for instance based on density function theory or more advances methods. The computational cost of such calculations, however, limits their application to small systems and short sampling times.

Future work under Section 3 should address the following three main questions:

Question 3.1: How does the morphology and surface functionalization influence ice nucleation?

Question 3.2: What are the molecular mechanisms of ice-nucleating particles and antifreeze proteins to control ice formation, and how are they regulated?

Question 3.3: What simulation techniques could be used to bridge the time-scale and size problems in ice nucleation (from full-atoms to coarse-grained methods)?

For Question 3.1, the computational findings on the heterogeneous nucleation of water roughly resemble the results seen for general models of crystallizing particles. Hence, the knowledge about the crystallization mechanism of generic crystals, such as colloidal or rare gas crystals, may improve the understanding of heterogeneous ice nucleation. The morphology of surfaces and the strengths of the crystallizing particles-surface interactions play a decisive role in the heterogeneous crystal nucleation [51]. Computer simulations and experimental investigations of colloidal crystal nucleation indicate that the curvature of the substrate affect the heterogeneous crystal nucleation. For example, only surfaces with curvature in a restricted range produce an enhancement of the nucleation rate $[52,53]$. 
The effect of small structured templates, on the other hand, depends on the precise structure of the seeds, which strongly enhance crystallization when commensurate to the crystal structure but do not affect the rate when incommensurate to it [54-56].

Computer simulations of ice nucleation on small AgI disks and plates reveal that the free energy barrier opposing ice nucleation is reduced by the presence of these nanoparticles [57]. Furthermore, the flexibility of the surfaces is a factor affecting ice nucleation characteristics [58], which is reflected on the colloidal level, where this flexibility is realized by the softness of crystallizing particles and apparently also enhances crystal formation [53]. The study of heterogeneous ice nucleation requires, as a first step, the distinction of fundamental classes of properties of the substance added to the water that affects the nucleation rate of ice. For instance the description of water at interfaces; polarization effects $[59,60]$, or changes in surface structure (hydroxylation) and finally the effect of defects [61]. Here, the use of models with different levels of accuracy could help to bridge the gap between fundamental theories and experiments. For instance, if the community performing controlled ice nucleation experiments could make efforts towards cleaner and better controlled conditions, where only few of the abovementioned parameters are introduced, simulations could be used to obtain insights at the molecular level about the effect of such parameters on the nucleation process and their relative importance.

For Question 3.2, research is needed to uncover the molecular mechanisms of ice-nucleating particles and antifreeze proteins. Freezing regulation activity involves one of the most difficult recognition problems in biology, the distinction between liquid water and ice [62]. Antifreeze proteins inhibit ice formation by adsorbing onto the surface of ice crystals and modifying their growth [63], while ice-nucleating particles act as catalysts inducing the formation of embryonic ice crystals at higher temperatures [64]. In recent years, antifreeze proteins and ice-nucleating particles have generated great interest in various fields of science [31,65-72]. Although theories and hypotheses have been formulated to explain the mechanism of their regulatory function, a molecular understanding of how they work is still lacking. Computer simulations could represent an invaluable tool towards this objective. On the one side, full atomistic simulations could provide a detailed description of the kinetics and thermodynamics of specific proteins at conditions similar to the one of highly controlled experiments [73]. On the other side, coarse-grained models could be used to answer questions related to the common features shared by the various proteins [74-77]. Quantitative coarse-grained protein models could potentially be used to even design artificial proteins with ice-nucleating or anti-freeze properties $[78,79]$.

For Question 3.3, simulation techniques are needed to bridge the time-scale and size problems in ice nucleation. In addition to the molecular interpretation of experimental observation, simulations represent also the bridge between fundamental models and accurate representations of physical systems. In particular, with computer simulations it is possible to isolate the fundamental parameters that control an experimentally observed phenomenon. Based on the tested models it is then possible to formulate general theories, which, in turn, can be used to make predictions or to translate natural phenomenon into novel technology. The description of complicated many-body dynamics, such as water-protein interactions or the nucleation of a crystal, typically requires high performance computing facilities. Full-atom simulations of such systems generally involve hundreds of thousands of water molecules, with dynamics taking microseconds or larger times, and are computationally very costly even for up-to-date computing resources. Moreover, the study of nucleation phenomena, related to long-range correlation between solvent degrees of freedom, make this approach simply prohibitive. For instance, for the study of protein induced ice nucleation, one of the main reasons for the complexity of the problem is because of the combination of several length scales (ranging from the water molecule scale of angstroms to the large proteins structures of the order of tens of nanometers) and time scales (fast water dynamics all the way to slow process such as protein folding).

A full understanding of the effect different aerosols may have on cloud formation, depends on an understanding of the interactions between them and the water in the atmosphere. For comparatively small length- and time-scales this knowledge can be gained by simulating systems on a quantum chemical level (i.e., one solves Schrödinger's equation), however, systematically 
extending these results to the dimensions at which nucleation takes place is one of today's main challenges. Promising approaches to this issue are to develop coarse-grained models, for example by abstracting the interactions between amino-acids $[78,79]$ or by using machine-learning methods like neural-networks [80], that learn the interactions between certain kinds of atoms resulting in an extension of the timescales that can be simulated by orders of magnitude. Given such an accurate model of the system, the investigation of the actual formation of a nucleus requires additional steps using algorithms dedicated to the simulation of phase transitions that further extend the observable timespans [81-84]. Such combinations of methods are examples of multiscale approaches, in which a phenomenon is studied at different time and length scales, allowing the theoretical description to span times from picoseconds to minutes, and size ranges from angstroms to microns. There are several schemes that allow for a bottom-up parametrization from accurate representations to a more coarse-grained one. A complete list is outside the scope of this work but it is important to mention few notable examples, including Inverse Boltzmann [85-87], Soft-Effective Segments [88-90], and Neural Networks [80].

\section{Identifying and Quantifying Contributions of Biological Ice Nuclei from Natural and Managed Environments}

Biological ice nuclei (cells of microorganisms such as bacteria [91], pollen [92,93], or biogenic particles produced from organic matter $[94,95]$ ) have the potential to initiate heterogeneous ice nucleation in clouds and create precipitation. Moreover, they likely are the most abundant atmospheric ice nuclei covering nucleation temperatures between $-2{ }^{\circ} \mathrm{C}$ and $-10^{\circ} \mathrm{C}$ [3], a temperature range critical for secondary ice formation [96]. It should be noted that recent studies examined feldspar samples of which some were ice active at a high temperature range $[97,98]$, but it remains to be seen which role these particles play in the atmosphere, since their abundance is unclear. The plant pathogenic bacterium, Pseudomonas syringae, is an important microbial ice nucleator that has been found in clouds, rain, and snow [9,99-103]. A handful of fungi have also been reported to be ice nucleators, including species of Fusarium and Mortierella [104-106]. Representatives of these fungal genera can be found in soils throughout the globe, and very recent research showed that they can serve as a reservoir of biological ice nuclei transferred to mineral particles [107]. Other genera of ice-nucleating microorganisms have been reported [108], but their relative abundance in the atmosphere and their potential role in atmospheric processes is presently unknown. Even more poorly understood are biological ice nuclei from aquatic sources. About 70 percent of the Earth's surface is covered with water-a huge reservoir for biological ice nuclei. Droplets containing biological ice nuclei can aerosolize from the water surface, liberating them into the atmosphere [109] where they can mediate pathogen dispersal, affect cloud formation as cloud condensation nuclei, and influence the earth's radiation budget. Research is needed to understand the relative contributions of aquatic and terrestrial sources of ice nuclei [95,110-113], and environmental conditions that trigger their release into the atmosphere [114].

Future work under Section 4 should address the following three main questions:

Question 4.1: What is the taxonomic, genetic, and functional diversity of biological ice nuclei in nature?

Question 4.2: What are the ecological roles of ice-nucleating organisms in terrestrial and aquatic environments?

Question 4.3: What are the contributions of biological ice nuclei from aquatic environments to atmospheric processes?

Question 4.1 addresses our need to explore and discover the range of diversity of biological ice nuclei in natural environments [2]. Most of the previous reports of biological ice nuclei have focused on culturable microbes (e.g., Pseudomonas syringae and Fusarium avenaceum) (e.g., [91,105]) or ubiquitous components of plant matter, such as pollen grains from common tree species [92] or decaying leaf litter [115]. Understudied are the unculturable microbial ice nucleators, biogenic macromolecules serving as ice nuclei $[94,116,117]$, microorganisms in harsh environments producing ice nuclei, and potential biogenic compounds produced by ice-nucleating plankton [24,95,118-120]. 
With new and improved taxonomic tools leveraging next generation sequencing [121], we can begin to probe the range of potential taxa that might act as ice nuclei or produce ice nuclei in different environments. Moreover, basic research is needed to describe the ice-nucleating processes by means of thermodynamics (see also 2.3 and 2.4) and to identify the chemical composition of biological ice nuclei, whose chemical nature is highly complex and poorly understood.

Question 4.2 is focused on a potential ecological advantage conferred by the ice-nucleation phenotype. Ice nucleation plays an important role in frost injury in crops ([122-126]; reviewed by [127]), and bacteria expressing ice-nucleating proteins may have a selective advantage as plant pathogens [108]. Ice-nucleating strains of Fusarium avenaceum [105] occupy a similar ecological niche (overwintering in cereal residues, and causing disease in small grains [128]) as non ice-nucleating strains of Fusarium graminearum [105], but the ecological role of the persistence of the ice-nucleating phenotype in these strains are presently unknown. Pollen from the same birch species (Betula pendula) was observed to be more ice active for Swedish than for Czech samples [116]. Some plants are able to acclimate to cold temperatures by expressing cold-induced genes, which likely serve to protect membranes from frost-induced injury (reviewed by [129]). Unknown is whether these anti-freezing mechanisms have played a unique role in the colonization of plants in cold environments, such as ecological zones of trees spanning altitudinal gradients along major mountain ranges. Schnell and Vali [95] described an increasing abundance of biological ice nucleating particles from terrestrial and marine sources from warmer to colder climate zones. Perhaps some environmental cues could cause some microbes to express ice-nucleating proteins in clouds $[130,131]$, which could in turn provide a selective advantage for the microbes in returning to surface of the Earth via precipitation [99].

Question 4.3 addresses important knowledge gaps in our understanding of aquatic sources of biological ice nuclei. Though terrestrial environments are often considered to be the main source of biological ice nuclei, research is needed to understand aquatic sources of ice nuclei in both freshwater [111,112] and marine systems $[24,95,113]$ (Figure 3). Recent work has been conducted in marine environments to find the connections between seawater properties and the composition of sea spray aerosol, and to examine the contribution of sea spray to atmospheric ice nucleating particles $[24,95,113,132,133]$. Unknown are potential seasonal fluctuations associated with aquatic ice nuclei (e.g., blooms in the spring and summer), and the contributions of melting glacial ice loaded with microbes [134]. Droplets containing biological ice nuclei have the potential to aerosolize from the water surface [109].

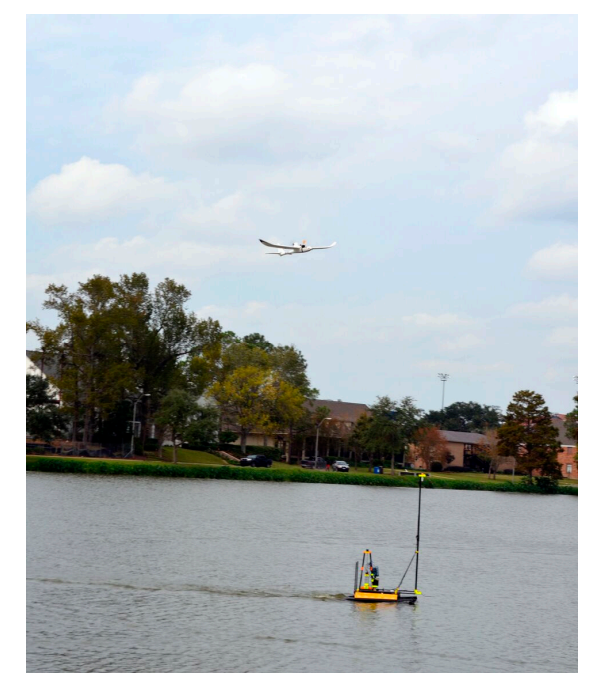

Figure 3. Teams of unmanned vehicles can be used to identify biological ice nucleators in natural and managed ecosystems. Here, an unmanned aircraft system (UAS) and an unmanned surface vehicle (USV) are being used to study microbial ice nucleators in the air and the water. The fixed wing UAS was flown legally under a Virginia Tech FAA COA following all guidelines and restrictions. 


\section{Examining the Role of Aging of Biological and Biogenic Ice Nuclei}

While the effects of aging (transformations, defined below) on mineral ice nuclei already are a topic of ongoing research (e.g., [10,65,135-139]), the influences of chemical aging on the ice nucleation potential of biogenic ice nuclei and/or ice-nucleating macromolecules [117] are still an open topic. The main reason for this is that the atmospheric relevance of biological and biogenic ice nuclei might have been considerably underestimated in the past. While most biological ice nuclei are primary biological aerosol particles (e.g., bacteria, fungi, pollen, leaf litter, viruses etc.), the definition of biogenic particles is more difficult. Beside nano-scale fragments, secretion and peel-off products, secondary organic aerosols also fall within this group when the educts were emitted from plants. This latter definition is not very clear and still demands discussion; as pointed out in the introduction of this manuscript, it is not the aim of the authors to find universally valid definitions but rather to report the present state of the discussion. Many primary biological aerosol particles are known to serve as excellent ice nuclei, which can undergo a wide range of atmospheric and non-atmospheric transformation processes, which can be of chemical, biological and morphological nature (Figure 4). Recent reviews by Rudich et al. [140] and by George and Abbatt [141] have summarized these aging effects on aerosols, but have not discussed their impact on the ice nucleation activity of these particles. The only available study is a recent paper by Brooks et al. [142], who have observed the changes of ice nucleation activity of soot due to the oxidation with ozone. No such information is available for the same effects on biological or biogenic aerosols. Also, chemical changes are not the only effect impacting ice nucleation ability. In general, the transformations can be divided into three categories: (1) microphysical transformation by agglomeration/fragmentation, drying/wetting, or freezing/melting/sublimation of biological ice nucleation active particles; (2) chemical transformation by oxidation, functionalization (e.g., nitration, sulfatisation), oligomerization, or degradation of ice-nucleating macromolecules; and (3) biological transformation by cellular responses induced by changing ambient conditions (atmospheric/environmental stress) that lead to enhanced or reduced production of ice-nucleating macromolecules. A recent study [107] showed that supermicron particles such as bacterial cells, fungal spores and pollen grains are relatively rare ice nuclei, while submicron particles, so-called nano-ice nucleating particles, are much more effective and wide spread in the environment. Biogenic ice-nucleating macromolecules such as protein complexes and polysaccharides can exist detached from their original carrier/source and still nucleate ice at temperatures as high as $-4{ }^{\circ} \mathrm{C}[104,105,116,117,143,144]$. Associated with soil dust particles, these ice-nucleating macromolecules may impact cloud glaciation indirectly, indicating a higher contribution and importance of biological ice nuclei than previously assumed [104,107,117]. For proteinaceous ice-nucleating macromolecules from the fungus Fusarium avenaceum, it was recently demonstrated that they can be adsorbed onto kaolinite, a common soil clay mineral, conferring their ice nucleation activity to the mineral particles [107]. Similar observations are reported by Augustin-Bauditz et al. [145], who investigated the ice nucleation behavior of particles consisting of a mixture of illite-NX and biological material washed of birch pollen grains. Nanometer-sized particles of biological and inorganic origin were found to be the most abundant particles in snow samples from different ecosystems [146].

Future work under Section 5 should address the following main questions:

Question 5.1: How is the ice nucleation activity of biogenic ice nuclei affected by atmospheric aging processes?

Question 5.2: What marker compounds should be used to investigate chemical aging processes?

For Question 5.1, little is known concerning how and to what extent atmospheric aging affects the ice nucleation activity of biogenic ice nuclei. The best characterized, biogenic, ice nucleation active structure is a betasheet protein produced by the bacterium Pseudomonas syringae and is anchored in its membrane [147]. The ice nucleation activity is dependent on the size of agglomerates of these proteins [148] and the chemistry of the cell membrane $[149,150]$. This protein is still ice nucleation active if removed from the membrane, as long as it is not denaturized. In the unbound state the protein 
shows a slightly decreased ice nucleation activity and a tendency to self-aggregation is observed. Aging processes of proteins were reviewed by Sharma and Graham [151]. Ice-nucleating macromolecules released from fungi are proteinaceous [152], but the ice-nucleating macromolecules derived from pollen might be different [143]. The fate of these ice-nucleating macromolecules, when separated from the mother particle by water suspension, is uncertain $[116,117]$. Furthermore, it is not clear if water-suspendable ice-nucleating macromolecules are accumulated in soils, re-dispersed by wind erosion processes, transported over longer distances, and undergo aging processes before acting as ice nuclei.

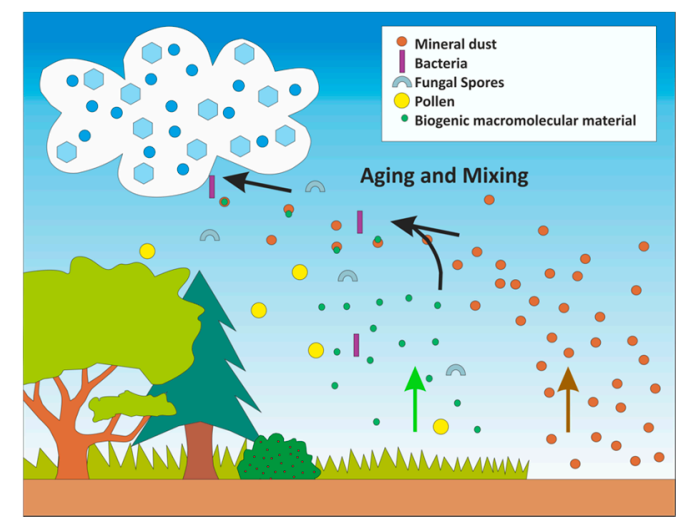

Figure 4. Naturally emitted primary aerosols vary widely in their composition depending on the biome and local vegetation of their origin. They cover a wide range of materials, like mineral dusts and other soil materials, different microorganisms, plant debris, and biogenic macromolecules, and mixtures of those. Many of these components are able to trigger atmospheric ice formation. In the atmosphere various mixing, agglomeration, and aging processes take place, which can affect the different ice nucleation activities.

Volatile organic compounds (isoprene and terpene) from biogenic emissions form secondary aerosol particles which can act as ice-nucleating particles after aging. Former studies have mostly focused on the chemical and physical characterization of the particles (e.g., [153]), but studies concerning ice nucleation are very limited and mainly focused on glassy aerosols and their ice nucleation behavior in the deposition mode [154-158]. Although studies exist examining organic molecules in the atmosphere and their properties concerning particle formation (e.g., [159,160]), almost no information exists about the ice nucleation potential of those biogenic secondary aerosol particles and their possible ice-nucleating constituents. Hence, more studies are needed investigating the ice nucleation activity of fresh and aged biogenic secondary organic aerosol particles. A recent study with $\alpha$-pinene as precursor and the related controversial discussion can be found in Ignatius et al. [161].

According to [162], aging of secondary organic aerosols and biogenic secondary aerosol particles might involve the following processes: (i) oxidation of condensed-phase organics by heterogeneous uptake of $\mathrm{OH}, \mathrm{O}_{3}, \mathrm{NO}_{2}, \mathrm{NO}_{3}$ or halogen atoms; (ii) further oxidation of first generation oxidation products in the gas phase with a subsequent partitioning into the particle phase and/or (iii) polymerization of condensed-phase organics. Such aging experiments clearly showed that the chemical composition constantly changes during experiments (e.g., [163-168]). Fragmentation is a possible pathway occurring under harsh oxidation conditions, but more often polymerization is observed. With ongoing aging, a steady increase in aerosol mass was found [166]. Two parameters are influenced by this chemical process. First, polarity and hydrophilicity are increased making water-uptake and thus immersion freezing more probable. Second, the mass-increase determines the transition of the aerosol between amorphous (semi)-solid, partially crystalline, and glass $[158,159,169]$. Furthermore, as the phase of the aerosol particles affects the time scales for the mass transfer, their ability to act 
as ice nuclei and other properties such as water uptake, evaporation, diffusion, adsorption and viscosity $[159,170-176]$, and the influence of chemical aging should be comprehensively characterized.

For Question 5.2, appropriate marker compounds should be used to investigate aging processes. To investigate aging processes and the degree of aging it is suitable to use marker compounds that can be found in the particle phase. Few studies already identified marker compounds for biogenic secondary aerosol particles (e.g., [177-181]) and for biomass burning secondary organic aerosols [180]. An important marker compound for aged biogenic secondary aerosol particles is 3-methyl-1,2,3-tricarboxylic acid (MBTCA, [177]). It is suggested to be formed by various precursor compounds and thus it can be considered as a multi-precursor aging marker compound [168]. Besides this, known early-generation oxidation products such as terpenylic acid [178] and pinic acid [182] can as well be used as marker compound for "fresh" secondary organic aerosol. Furthermore, it was shown in studies investigating biomass burning aerosol that levoglucosan is an important biomass burning marker compound $[183,184]$. All organic matter undergoes substantial aging process in the atmosphere. Ice nucleation sites might be altered or destroyed because of aging processes.

\section{Conducting Targeted Sampling Campaigns in Clouds}

A wide range of previous coordinated field measurements have elucidated key aerosol sources and processes concerning heterogeneous ice nucleation in the troposphere (measurements reviewed by [185]; secondary ice reviewed by [186]; with an overview of the monograph by [5]). For example, previous field campaigns have targeted the roles of ice initiation and secondary ice multiplication in clouds such as the Ice in Clouds Experiment-Layer Clouds (ICE-L; 2007) in Colorado, ICE-Tropical Clouds (ICE-T; 2011) in St. Croix, and ICE-Dust (ICE-D; 2015) in Cape Verde (e.g., [187-194]). Although these and other previous, parallel studies have yielded noteworthy results, our overall understanding of heterogeneous ice nucleation remains limited due to: (1) the complexities involved with heterogeneous ice nucleation processes and their role in modulation of precipitation phase, location, and quantity relative to secondary ice and atmospheric dynamical processes and (2) variability of these processes within different cloud regimes. Further, developing a connection between near-surface sources of ice-nucleating particles and the mechanisms necessary to transporting such particles to levels where cloud formation occurs is needed to improve process understanding of aerosol-cloud-precipitation interactions. Modeling studies often yield conflicting results in quantifying the extent to which ice-nucleating particles impact precipitation, ranging anywhere from a negligible to $67 \%$ increase in precipitation quantity [195-197]. The need to constrain heterogeneous ice nucleation processes to improve model simulations, from source to sink, is evident. Although this burgeoning area of research has resurged over the last couple of decades, additional studies are needed over different temporal and spatial scales to accurately represent ice nucleation process parameterizations in models. Thus, we recommend that a key area of focus for future targeted sampling campaigns is on elucidating the extent to which ice-nucleating particles from tropospheric aerosol sampling in addition to cloud residuals induce cloud ice development relative to other processes in the cloud system, such as secondary ice formation and atmospheric dynamics (Figure 5). Additionally, a wide range of studies should be conducted in various cloud environments, locations globally, and time scales.

Future work under Section 6 should address the following three main questions:

Question 6.1: What is the atmospheric abundance and sources of particles that have the potential to nucleate ice in non-precipitating and precipitating clouds across a range of temperatures and cloud types?

Question 6.2: What are the relative contributions of heterogeneous ice nucleation and secondary ice formation processes to ice crystal number concentrations in clouds?

Question 6.3: What is the role of dynamics and atmospheric state versus aerosols as ice-nucleating particles in modulating cloud micro- and macrophysical properties? 
For Question 6.1, future field campaigns should focus on determining the number and sources of particles that have the capability to nucleate ice in a variety of non-precipitating and precipitating cloud and temperature regimes. Further, precipitation phase is variable depending on latitudinal zones and surface cover (i.e., ocean or land), thus sampling should be conducted at a wide range of locations. Several studies have focused on laboratory examination of ice nucleation efficiency of mineral dust, soil dust, soot, and biological particles (i.e., pollen, bacteria, spores, and leaf litter) in the immersion and deposition freezing modes, either from commercial standards or from aerosol samples collected at the ground level. Analyzing ice-nucleating particle concentrations and/or composition in collected precipitation samples has been conducted in several locations over the globe $[68,69,198,199]$; however, this technique encompasses caveats such as in-cloud scavenging and modification of the original ice-nucleating particles from exposure to a solution of water and soluble aerosol components [200] and the determination of atmospheric relevant number concentrations of ice-nucleating particles from precipitation samples [201]. Several previous field measurements have focused on determining the sources of particles that nucleate ice in-cloud via aircraft (e.g., [193,202,203]), however, the coverage of observations in multiple locations and cloud regimes, and on a wide time scale is limited on a global scale. Sampling in-cloud with selective inlets, such as counterflow virtual impactors (CVIs), are helpful in reducing sampling error by separating cloud particle residuals from interstitial aerosol [204]. Additionally, recent development of an ice-selective CVI (i.e., that separates interstitial aerosol, supercooled liquid droplets, and ice crystals) can enable more detailed characterization of ice residuals by segregating cloud liquid from ice [205].

For Question 6.2, we recommend future field campaigns attempt to (1) elucidate the contribution of heterogeneous ice nucleation as compared to secondary ice formation processes and (2) determine the particles that nucleated cloud ice as compared to interstitial aerosols or aerosols scavenged in-cloud. Previous studies have demonstrated that the number of ice-nucleating particles can be several orders of magnitude less than cloud ice particle number concentrations within the same cloud over relative short time periods (5-10 $\mathrm{min}$ ), namely because of: (1) secondary ice formation processes such as accretion and subsequent rime-splintering; (2) removal of small droplets via collision with larger droplets during air parcel ascent; (3) drop freezing during evaporation; (4) activation of droplet evaporation residues; and (5) underestimation of the contact freezing mode [206-213]. When graupel collide with larger supercooled droplets $(>24 \mu \mathrm{m})$ between $-3{ }^{\circ} \mathrm{C}$ and $-8{ }^{\circ} \mathrm{C}$ in moderate updrafts, they may eject shards of ice $[189,214]$, subsequently increasing cloud ice particle number concentration via growth of the ice shards into needles or columns from vapor deposition or additional riming. Other secondary processes that yield high cloud ice particle number concentrations include fracturing of ice particles because of ice particle-ice particle or graupel-graupel collisions [215]; and production of multiple ice particles during the evaporation of single particles (including aggregates) or associated with vapor growth at $-5^{\circ} \mathrm{C}$, without the need for riming [216]. These processes (i.e., riming, secondary ice formation, evaporation and reactivation, scavenging, and contact freezing) render difficulty in determining the actual ice-nucleating particles in-cloud, and despite current knowledge, are still poorly understood. Future studies should use a comprehensive suite of measurements to focus on multiple processes at once and fully elucidate the contribution from each process. Such measurements should include ice-nucleating particle concentration, composition, and morphology in the context of meteorological parameter measurements including temperature, saturation about water and ice, vertical updraft velocity, and orographic or frontal forcing-in cloud environments either via aircraft campaigns utilizing traditional plane platforms, unmanned aerial systems (UAS), and/or balloon-borne measurement platforms as highlighted in Section 7. However, to fully address Question 6.3, it is essential that these observations should be integrated into numerical modeling studies for project design and evaluation of processes leading to cloud ice formation and precipitation. Furthermore, an approach to cloud studies that is more statistical may be necessary. Future campaigns could focus on comparing in-cloud ice-nucleating particles via aircraft measurements with ice-nucleating particles found in ground-based precipitation sample, considering precipitation sample collection is relative simple, cost and time efficient, and 
capable of producing long-term measurements of ice-nucleating particles. Another viable option for in-cloud measurements includes mountaintop atmospheric research facilities that are well-established and frequently exposed to in-cloud conditions [217-220].
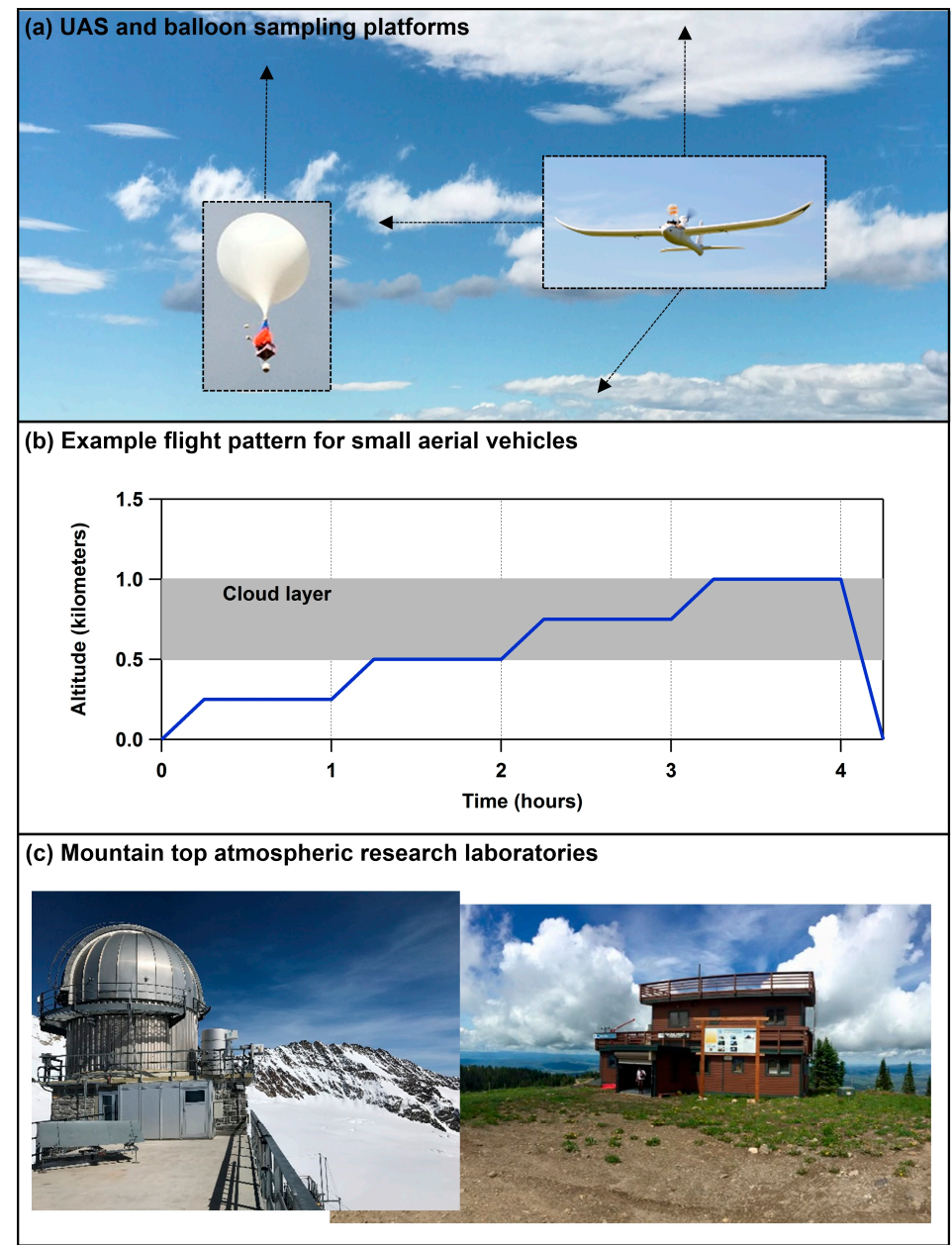

Figure 5. Conceptual schematic of future field sampling needs. (a) Examples of small aerial platforms that could be utilized to profile and collect samples in cloud environments, including launched balloons and unmanned aerial systems (UASs). Potential payloads could include aerosol filter collection, real time aerosol size distributions, and miniaturized cloud probes. Filters could be used for offline analyses of aerosol composition and ice-nucleating particle concentrations from cloud ice residuals. (b) Example of flight pattern for small aerial systems. Flight would profile below cloud, at cloud base, in-cloud, and at cloud top to enable comparison of aerosol and ice nucleation properties in the different regime layers. (c) Pictures of mountain top atmospheric research laboratories, including Jungfraujoch in Switzerland (left) and Storm Peak Laboratory in Steamboat Springs, Colorado, USA (right).

\section{Designing Lab and Field Experiments to Increase Our Understanding of the Role of Ice-Nucleating Particles in the Atmosphere}

This section explores open issues regarding primary ice nucleation in the atmosphere, including the supportive role of laboratory measurements for this topic. Important and recent findings include the following: (1) among mineral dusts, feldspars are particularly ice active (e.g., $[65,97,98])$; (2) for biological systems, organic macromolecules are likely responsible for the observed ice activity; and (3) that the ice activity in soil dusts often is related to its biological or organic content (e.g., [94,145,221,222]). For a comprehensive review of recent findings on ice-nucleating particles see Kanji et al. [10], while older reviews can be found in $[2,3,223]$. A number of different parameterizations have been used 
in atmospheric modeling to describe temperature dependent ice-nucleating particle concentrations (e.g., $[195,224,225])$. Based on atmospheric observations, these parameterizations feature an exponential increase of ice-nucleating particle concentration with decreasing temperature. However, they do not allow for a variation of these concentrations at single temperatures, which may extend to different orders of magnitude $[24,201]$. These models represent very simple representations of atmospheric ice nucleation. More recently, DeMott et al. [23] introduced a successful temperature dependent parameterization that depends on the total particle number concentration above $500 \mathrm{~nm}$ in diameter. Other temperature dependent parameterizations predict surface area scaled ice particle concentrations (e.g., [226]) based on ice nucleation active surface site or mass density (i.e., the number of ice-nucleating sites per unit particle surface area or mass, respectively). These schemes neglect the stochastic nature (i.e., time dependent nature of the nucleation process), which is certainly feasible for larger scale non-cloud-resolving models, but may introduce errors when used in smaller scale models. For such applications (e.g., Large Eddy Simulation (LES) modeling), the stochastic nature of the ice nucleation process can be accounted for by parameterizations for nucleation rate (coefficients) or contact angle distributions $[137,227,228]$, or considering water activity [120]. All of these more complex models also need aerosol properties on different levels (Figure 6). For all mentioned parameterizations, caveats and assumptions exist which limit their use, and additional information may also be required in their implementation, such as knowledge of different ice-nucleating particle types, accounting for all particle sizes [219] or knowledge of different types of air masses [229].

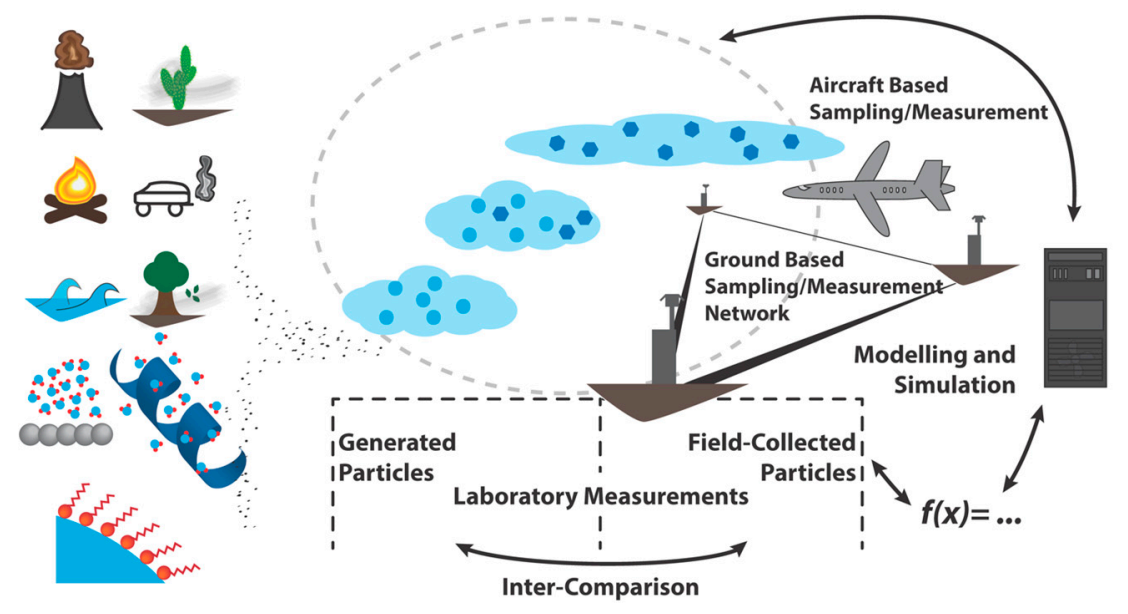

Figure 6. Flow diagram illustrating the role of laboratory measurements play to improve the representation of primary ice formation in atmospheric clouds. Laboratory investigations and inter-comparison studies on natural and surrogate ice-nucleating particle types from such sources as volcanic ash, desert dust, biomass burning, combustion, sea spray, leaf litter, soil dust, idealized surfaces used in molecular dynamic simulations, macromolecules and surfactants will assist in standardization and protocol development for future modeling and field campaigns. This will result in useful parameterizations for atmospheric computational modeling of ice in clouds. In turn, the results of modeling and field studies can also develop new parameterizations testable in a lab or field setting. The central role of the laboratory is to bridge the gap between the molecular level and cloud system understanding.

Future work under Section 7 should address the following main questions:

Question 7.1: What is the role of laboratory examinations for ice-nucleating particles for atmospheric applications?

Question 7.2: What is the spatial and temporal distribution of ice nucleation active particles and their properties worldwide? 
Question 7.3: What are suitable concepts for parameterizing atmospheric ice nucleation in different scale models?

For Question 7.1, it is known that atmospheric ice-nucleating particles are active in the temperature range from slightly below $0{ }^{\circ} \mathrm{C}$ down to $-40{ }^{\circ} \mathrm{C}$ and below, and occur over a wide range of concentrations (from a handful per $\mathrm{m}^{3}$, up to hundreds per liter). Various instruments exist for their detection, utilizing different measurement principles and techniques (e.g., [230]) and differing in temperature ranges, time scales and detection limit of ice-nucleating particle concentration. Laboratory studies are a very valuable tool for carrying out instrument inter-comparisons, some of which recently took place $[137,230,231]$. Furthermore, different measurement techniques, different particle generation techniques (e.g., [230,232]) and other experimental differences should be elucidated by developing standards and protocols to ensure quality and comparability of atmospheric ice nucleation particle measurements. In this context, useful reference substances should be identified and characterized, and standardized particle generation and sampling techniques should be developed to aide offline testing and evaluation of measurement devices prior to their application in field measurements.

For Question 7.2, the retrieval of concentrations and compositions of ice-nucleating particles worldwide is necessary, as it aides in assessing the influence of primary ice nucleation on cloud radiative properties and precipitation formation. This research question is naturally linked to Section 6 , which focuses on airborne measurements. While it is important to measure at cloud levels, these measurements are expensive and typically provide only small glimpses in space and time. Therefore, complementing them with ground-based sampling and establishing a connection between values derived from ground-based measurements and those obtained at cloud levels is needed. In this context, both short term campaigns (e.g., to examine specific atmospheric dust or marine biogenic aerosols) and long term measurements (e.g., including globally distributed observatories at representative locations), are highly desirable to collect more information on the spatial and temporal distributions of ice-nucleating particles, their sources, their transport, evolution and sinks. This approach is similar to activities concerning the determination of atmospheric cloud condensation nuclei properties that started some years ago, and that are now resulting in an increasing wealth of these data (e.g., the European infrastructure ACTRIS and the Global Aerosol Synthesis and Science Project, GASSP [233]. Such data are necessary and valuable for improving results from global climate modeling. Long-term atmospheric measurements of ice-nucleating particles are also recommended by Seinfeld et al. [234], who noted that these measurements are challenging but nevertheless necessary to improve our fundamental understanding of the role of aerosol-cloud interactions in the climate system.

For Question 7.3, existing parameterization concepts will have to be expanded and tested against measurements of atmospheric ice nucleation particle concentrations at different scales. It is also important to determine a small number of ice-nucleating particles types or groups, which describe the overall atmospheric situation sufficiently well. This was done by Wilson et al. [113], where only marine biogenic and K-feldspar particles were considered to model concentrations of ice-nucleating particles worldwide. A variability of atmospheric ice-nucleating particle concentrations due in part to source and removal processes [199], might further complicate the derivation of simple parameterizations. Additional parameters such as wind speed and/or the fraction of water vapor lost from an air mass by precipitation prior to sampling might have to be considered. However, the parameter(s) on which parameterization schemes should be based and the number of parameters needed is for the future to show. Once solved, the determination of (an) alternative parameter(s) will enable a better and more standardized incorporation of the ice nucleation process in atmospheric models, where, however, models on different scales might have to be treated differently.

\section{Conclusions: From Workshop Ideation to Action and Implementation}

In this perspectives paper, we identified 17 unanswered questions in the study of ice nucleation. Now, our task as a research community is to find answers to these questions, and translate our ideas into action. There was general agreement among the workshop attendees that: (1) public relations 
must shed light on the research, education, and outreach being done by the ice nucleation community; (2) resources should be allocated to support ongoing and future research on ice nucleation; and (3) young scientists should be supported and mentored to ensure the future of the discipline. We need to build interdisciplinary teams of atmospheric scientists, chemists, physicists, biologists, engineers, hydrologists, meteorologists, and political scientists. These teams should include both senior and early career scientists developing new cutting-edge methods and unique approaches. These teams need to work together to establish and maintain a common, unified language for ice nucleation research. Vali et al. [15] started introducing such a common language by defining important terms and proposing acronyms. Despite this valuable incentive, there is still work to do to unify the language among the different communities dealing with ice nucleation.

Acknowledgments: The authors thank the many workshop participants for their ideas and constructive criticisms in the development of this document. We also like to thank the Italian Cultural Institute in Vienna (Ernst Kanitz) for hosting both workshops. The workshops were supported in part by contributions to H. Grothe from the ESF research networking Programme on the Micro-Dynamics of Ice (http:// microdice.eu/) and the DFG funded Ice Nuclei research UnIT (INUIT, FOR 1525), WE 4722/1-2 (http:/ / www.ice-nuclei.de/the-inuit-project/), and small grants from a number of companies (LH Vakuum Technik-Oerlikon Leybold Vaccum, Pfeiffer Vacuum Austria $\mathrm{GmbH}$, Bruker Austria $\mathrm{GmbH}$, and Droplet Measurement Technologies). Additional support for the workshops was provided to $\mathrm{H}$. Grothe in the form of travel grants through the EGU. I. Coluzza and V. Bianco were supported in part from the Austrian Science Fund (FWF) project P26253-N27. Writing of this manuscript was supported in part by grants to D.G. Schmale through the National Science Foundation (NSF) under Grant Numbers DEB-1241068 (Dimensions: Collaborative Research: Research on Airborne Ice-Nucleating Species (RAINS)) and DGE-0966125 (IGERT: MultiScale Transport in Environmental and Physiological Systems (MultiSTEPS)) and to H. Grothe by the Austrian Research Fund FWF under grant number P26040 (The Ice Nucleation Activity of Carbonaceous Particles). J. Fröhlich-Nowoisky and U. Pöschl acknowledge support from the Deutsche Forschungsgemeinschaft (DFG, FR3641/1-2, FOR 1525 INUIT). Any opinions, findings, and conclusions or recommendations expressed in this material are those of the authors and do not necessarily reflect the views of the sponsors.

Author Contributions: I.C., J.C., M.J.R., and H.W. contributed equally to the document as section leaders, are listed in alphabetical order, and should be considered co-first authors. H.G. and D.G.S. organized the international workshops on ice nucleation, led the writing and organization of the manuscript, and also served as section leaders. The remaining authors (P.A.A., V.B., Y.B., C.D., L.F., J.F.-N., H.H., S.J., Z.A.K., G.M., B.M., C.M., A.M., U.P., M.S., J.S., E.S., and F.S.) contributed to discussion and the writing/editing of the manuscript.

Conflicts of Interest: The authors declare no conflict of interest. The sponsors of this work had no role in the design of the study; in the collection, analyses, or interpretation of data; in the writing of the manuscript, and in the decision to publish the results.

\section{References}

1. Pruppacher, H.R.; Klett, J.D. Microphysics of Clouds and Precipitation Kluwer; Springer: Dordrecht, The Netherlands, 2010; ISBN 978-0-306-48100-0.

2. Szyrmer, W.; Zawadzki, I. Biogenic and anthropogenic sources of ice-forming nuclei: A review. Bull. Am. Meteorol. Soc. 1997, 78, 209-228. [CrossRef]

3. Hoose, C.; Möhler, O. Heterogeneous ice nucleation on atmospheric aerosols: A review of results from laboratory experiments. Atmos. Chem. Phys. 2012, 12, 9817. [CrossRef]

4. DeMott, P.J.; Möhler, O.; Stetzer, O.; Vali, G.; Levin, Z.; Petters, M.D.; Murakami, M.; Leisner, T.; Bundke, U.; Klein, H. Resurgence in ice nuclei measurement research. Bull. Am. Meteorol. Soc. 2011, 92, 1623-1635. [CrossRef]

5. McFarquhar, G.M.; Baumgardner, D.; Heymsfield, A.J. Background and Overview. Meteorol. Monogr. 2017, 58, 5-9. [CrossRef]

6. Ward, P.J.; DeMott, P.J. Preliminary experimental evaluation of Snomax (TM) snow inducer, nucleus Pseudomonas syringae, as an artificial ice for weather modification. J. Weather Modif. 1989, 21, 9-13.

7. Li, J.; Lee, T.C. Bacterial ice nucleation and its potential application in the food industry. Trends Food Sci. Technol. 1995, 6, 259-265. [CrossRef]

8. Kim, P.; Wong, T.S.; Alvarenga, J.; Kreder, M.J.; Adorno-Martinez, W.E.; Aizenberg, J. Liquid-infused nanostructured surfaces with extreme anti-ice and anti-frost performance. ACS Nano 2012, 6, 6569-6577. [CrossRef] [PubMed] 
9. Morris, C.E.; Sands, D.C.; Bardin, M.; Jaenicke, R.; Vogel, B.; Leyronas, C.; Ariya, P.A.; Psenner, R. Microbiology and atmospheric processes: Research challenges concerning the impact of airborne micro-organisms on the atmosphere and climate. Biogeosciences 2011, 8, 17. [CrossRef]

10. Kanji, Z.A.; Ladino, L.A.; Wex, H.; Boose, Y.; Burkert-Kohn, M.; Cziczo, D.J.; Krämer, M. Chapter 1: Overview of Ice Nucleating Particles. Meteorol. Monogr. 2017, 58, 1. [CrossRef]

11. Geiger, F.M.; Tridico, A.C.; Hicks, J.M. Second harmonic generation studies of ozone depletion reactions on ice surfaces under stratospheric conditions. J. Phys. Chem. B 1999, 103, 8205-8215. [CrossRef]

12. McNeill, V.F.; Loerting, T.; Geiger, F.M.; Trout, B.L.; Molina, M.J. Hydrogen chloride-induced surface disordering on ice. Proc. Natl. Acad. Sci. USA 2006, 103, 9422-9427. [CrossRef] [PubMed]

13. Setyan, A.; Sauvain, J.J.; Rossi, M.J. The use of heterogeneous chemistry for the characterization of functional groups at the gas/particle interface of soot and TiO2 nanoparticles. Phys. Chem. Chem. Phys. 2009, 11, 6205-6217. [CrossRef] [PubMed]

14. Wex, H.; DeMott, P.J.; Tobo, Y.; Hartmann, S.; Rösch, M.; Clauss, T.; Tomsche, L.; Niedermeier, D.; Stratmann, F. Kaolinite particles as ice nuclei: Learning from the use of different kaolinite samples and different coatings. Atmos. Chem. Phys. 2014, 14, 5529-5546. [CrossRef]

15. Vali, G.; DeMott, P.J.; Möhler, O.; Whale, T.F. Technical Note: A proposal for ice nucleation terminology. Atmos. Chem. Phys. 2015, 15, 10263-10270. [CrossRef]

16. Marcolli, C. Deposition nucleation viewed as homogeneous or immersion freezing in pores and cavities. Atmos. Chem. Phys. 2014, 14, 2071-2104. [CrossRef]

17. Kittaka, S.; Ishimaru, S.; Kuranishi, M.; Matsuda, T.; Yamaguchi, T. Enthalpy and interfacial free energy changes of water capillary condensed in mesoporous silica, MCM-41 and SBA-15. Phys. Chem. Chem. Phys. 2006, 8, 3223-3231. [CrossRef] [PubMed]

18. Persiantseva, N.M.; Popovicheva, O.B.; Shonija, N.K. Wetting and hydration of insoluble soot particles in the upper troposphere. J. Environ. Monit. 2004, 6, 939-945. [CrossRef] [PubMed]

19. Hiranuma, N.; Möhler, O.; Yamashita, K.; Tajiri, T.; Saito, A.; Kiselev, A.; Hoffmann, N.; Hoose, C.; Jantsch, E.; Koop, T. Ice nucleation by cellulose and its potential contribution to ice formation in clouds. Nat. Geosci. 2015, 8, 273. [CrossRef]

20. Diehl, K.; Mitra, S.K. A laboratory study of the effects of a kerosene-burner exhaust on ice nucleation and the evaporation rate of ice crystals. Atmos. Environ. 1998, 32, 3145-3151. [CrossRef]

21. Gorbunov, B.; Baklanov, A.; Kakutkina, N.; Toumi, R.; Windsor, H.L. Ice nucleation on soot particles. J. Aerosol Sci. 1998, 29, S1055-S1056. [CrossRef]

22. Popovicheva, O.; Kireeva, E.; Persiantseva, N.; Khokhlova, T.; Shonija, N.; Tishkova, V.; Demirdjian, B. Effect of soot on immersion freezing of water and possible atmospheric implications. Atmos. Res. 2008, 90, 326-337. [CrossRef]

23. DeMott, P.J.; Prenni, A.J.; Liu, X.; Kreidenweis, S.M.; Petters, M.D.; Twohy, C.H.; Richardson, M.S.; Eidhammer, T.; Rogers, D.C. Predicting global atmospheric ice nuclei distributions and their impacts on climate. Proc. Natl. Acad. Sci. USA 2010, 107, 11217-11222. [CrossRef] [PubMed]

24. DeMott, P.J.; Hill, T.C.; McCluskey, C.S.; Prather, K.A.; Collins, D.B.; Sullivan, R.C.; Ruppel, M.J.; Mason, R.H.; Irish, V.E.; Lee, T. Sea spray aerosol as a unique source of ice nucleating particles. Proc. Natl. Acad. Sci. USA 2016, 113, 5797-5803. [CrossRef] [PubMed]

25. Benson, S.W. Thermochemical Kinetics; Wiley: New York, USA, 1976; ISBN 0-471-06781-4.

26. Křepelová, A.; Bartels-Rausch, T.; Brown, M.A.; Bluhm, H.; Ammann, M. Adsorption of acetic acid on ice studied by ambient-pressure XPS and partial-electron-yield NEXAFS spectroscopy at 230-240 K. J. Phys. Chem. A 2013, 117, 401-409. [CrossRef] [PubMed]

27. Orlando, F.; Waldner, A.; Bartels-Rausch, T.; Birrer, M.; Kato, S.; Lee, M.T.; Proff, C.; Huthwelker, T.; Kleibert, A.; Van Bokhoven, J. The Environmental Photochemistry of Oxide Surfaces and the Nature of Frozen Salt Solutions: A New in Situ XPS Approach. Top. Catal. 2016, 59, 591-604. [CrossRef]

28. Wei, X.; Miranda, P.B.; Shen, Y.R. Surface vibrational spectroscopic study of surface melting of ice. Phys. Rev. Lett. 2001, 86, 1554. [CrossRef] [PubMed]

29. Pandey, R.; Usui, K.; Livingstone, R.A.; Fischer, S.A.; Pfaendtner, J.; Backus, E.H.; Nagata, Y.; Fröhlich-Nowoisky, J.; Schmüser, L.; Mauri, S.; Scheel, J.F.; Knopf, D.A.; Pöschl, U.; Bonn, M.; Weidner, T. Ice-nucleating bacteria control the order and dynamics of interfacial water. Sci. Adv. 2016, 2, e1501630. [CrossRef] [PubMed] 
30. Sanz, E.; Vega, C.; Espinosa, J.R.; Caballero-Bernal, R.; Abascal, J.L.F.; Valeriani, C. Homogeneous ice nucleation at moderate supercooling from molecular simulation. J. Am. Chem. Soc. 2013, 135, 15008-15017. [CrossRef] [PubMed]

31. Matsumoto, M.; Saito, S.; Ohmine, I. Molecular dynamics simulation of the ice nucleation and growth process leading to water freezing. Nature 2002, 416, 409-413. [CrossRef] [PubMed]

32. Lupi, L.; Molinero, V. Does hydrophilicity of carbon particles improve their ice nucleation ability? J. Phys. Chem. A 2014, 118, 7330-7337. [CrossRef] [PubMed]

33. Lupi, L.; Hudait, A.; Molinero, V. Heterogeneous nucleation of ice on carbon surfaces. J. Am. Chem. Soc. 2014, 136, 3156-3164. [CrossRef] [PubMed]

34. Johnston, J.C.; Molinero, V. Crystallization, melting, and structure of water nanoparticles at atmospherically relevant temperatures. J. Am. Chem. Soc. 2012, 134, 6650-6659. [CrossRef] [PubMed]

35. Moore, E.B.; Molinero, V. Is it cubic? Ice crystallization from deeply supercooled water. Phys. Chem. Chem. Phys. 2011, 13, 20008-20016. [CrossRef] [PubMed]

36. Cox, S.J.; Kathmann, S.M.; Slater, B.; Michaelides, A. Molecular simulations of heterogeneous ice nucleation. I. Controlling ice nucleation through surface hydrophilicity. J. Chem. Phys. 2015, 142, 184704. [CrossRef] [PubMed]

37. Cox, S.J.; Kathmann, S.M.; Slater, B.; Michaelides, A. Molecular simulations of heterogeneous ice nucleation. II. Peeling back the layers. J. Chem. Phys. 2015, 142, 184705. [CrossRef] [PubMed]

38. Cox, S.J.; Kathmann, S.M.; Purton, J.A.; Gillan, M.J.; Michaelides, A. Non-hexagonal ice at hexagonal surfaces: The role of lattice mismatch. Phys. Chem. Chem. Phys. 2012, 14, 7944-7949. [CrossRef] [PubMed]

39. Yan, J.Y.; Patey, G.N. Heterogeneous ice nucleation induced by electric fields. J. Phys. Chem. Lett. 2011, 2, 2555-2559. [CrossRef]

40. Yan, J.Y.; Patey, G.N. Molecular dynamics simulations of ice nucleation by electric fields. J. Phys. Chem. A 2012, 116, 7057-7064. [CrossRef] [PubMed]

41. Yan, J.Y.; Patey, G.N. Ice nucleation by electric surface fields of varying range and geometry. J. Chem. Phys. 2013, 139, 144501. [CrossRef] [PubMed]

42. Pedevilla, P.; Cox, S.J.; Slater, B.; Michaelides, A. Can ice-like structures form on non-ice-like substrates? The example of the K-feldspar microcline. J. Phys. Chem. C 2016, 120, 6704-6713. [CrossRef] [PubMed]

43. Bi, Y.; Cabriolu, R.; Li, T. Heterogeneous ice nucleation controlled by the coupling of surface crystallinity and surface hydrophilicity. J. Phys. Chem. C 2016, 120, 1507-1514. [CrossRef]

44. Kiselev, A.; Bachmann, F.; Pedevilla, P.; Cox, S.J.; Michaelides, A.; Gerthsen, D.; Leisner, T. Active sites in heterogeneous ice nucleation-the example of K-rich feldspars. Science 2017, 355, 367-371. [CrossRef] [PubMed]

45. Abascal, J.L.F.; Sanz, E.; Garcia Fernandez, R.; Vega, C. A potential model for the study of ices and amorphous water: TIP4P/Ice. J. Chem. Phys. 2005, 122, 234511. [CrossRef] [PubMed]

46. Liou, Y.C.; Tocilj, A.; Davies, P.L.; Jia, Z. Mimicry of ice structure by surface hydroxyls and water of a $\beta$-helix antifreeze protein. Nature 2000, 406, 322-324. [PubMed]

47. Molinero, V.; Moore, E.B. Water modeled as an intermediate element between carbon and silicon. J. Phys. Chem. B 2008, 113, 4008-4016. [CrossRef] [PubMed]

48. Bianco, V.; Franzese, G.; Dellago, C.; Coluzza, I. Role of Water in the Selection of Stable Proteins at Ambient and Extreme Thermodynamic Conditions. Phys. Rev. X 2017, 7, 21047. [CrossRef]

49. Abascal, J.L.; Vega, C. A general purpose model for the condensed phases of water: TIP4P/2005. J. Chem. Phys. 2005, 123, 234505. [CrossRef] [PubMed]

50. Vega, C.; Abascal, J.L. Simulating water with rigid non-polarizable models: A general perspective. Phys. Chem. Chem. Phys. 2011, 13, 19663-19688. [CrossRef] [PubMed]

51. Lederer, A.; Franke, M.; Schöpe, H.J. Heterogeneous nucleation and microstructure formation in colloidal model systems with various interactions. Eur. Phys. J. Spec. Top. 2014, 223, 389-407. [CrossRef]

52. Cacciuto, A.; Auer, S.; Frenkel, D. Onset of heterogeneous crystal nucleation in colloidal suspensions. Nature 2004, 428, 404-406. [CrossRef] [PubMed]

53. Sandomirski, K.; Walta, S.; Dubbert, J.; Allahyarov, E.; Schofield, A.B.; Löwen, H.; Richtering, W.; Egelhaaf, S.U. Heterogeneous crystallization of hard and soft spheres near flat and curved walls. Eur. Phys. J. Spec. Top. 2014, 223, 439-454. [CrossRef] 
54. Hermes, M.; Vermolen, E.C.M.; Leunissen, M.E.; Vossen, D.L.J.; van Oostrum, P.D.J.; Dijkstra, M.; van Blaaderen, A. Nucleation of colloidal crystals on configurable seed structures. Soft Matter 2011, 7, 4623-4628. [CrossRef]

55. Jungblut, S.; Dellago, C. Heterogeneous crystallization on tiny clusters. EPL Europhys. Lett. 2011, 96, 56006. [CrossRef]

56. Jungblut, S.; Dellago, C. Crystallization on prestructured seeds. Phys. Rev. E 2013, 87, 12305. [CrossRef] [PubMed]

57. Zielke, S.A.; Bertram, A.K.; Patey, G.N. Simulations of ice nucleation by kaolinite (001) with rigid and flexible surfaces. J. Phys. Chem. B 2015, 120, 1726-1734. [CrossRef] [PubMed]

58. Zielke, S.A.; Bertram, A.K.; Patey, G.N. Simulations of ice nucleation by model AgI disks and plates. J. Phys. Chem. B 2016, 120, 2291-2299. [CrossRef] [PubMed]

59. Viererblová, L.; Kolafa, J. A classical polarizable model for simulations of water and ice. Phys. Chem. Chem. Phys. 2011, 13, 19925-19935. [CrossRef] [PubMed]

60. Wang, L.P.; Head-Gordon, T.; Ponder, J.W.; Ren, P.; Chodera, J.D.; Eastman, P.K.; Martinez, T.J.; Pande, V.S. Systematic improvement of a classical molecular model of water. J. Phys. Chem. B 2013, 117, 9956-9972. [CrossRef] [PubMed]

61. Brukhno, A.V.; Anwar, J.; Davidchack, R.; Handel, R. Challenges in molecular simulation of homogeneous ice nucleation. J. Phys. Condens. Matter 2008, 20, 494243. [CrossRef]

62. Sharp, K.A. A peek at ice binding by antifreeze proteins. Proc. Natl. Acad. Sci. USA 2011, 108, 7281-7282. [CrossRef] [PubMed]

63. Raymond, J.A.; DeVries, A.L. Adsorption inhibition as a mechanism of freezing resistance in polar fishes. Proc. Natl. Acad. Sci. USA 1977, 74, 2589-2593. [CrossRef] [PubMed]

64. Duman, J.G. Antifreeze and ice nucleator proteins in terrestrial arthropods. Annu. Rev. Physiol. 2001, 63, 327-357. [CrossRef] [PubMed]

65. Atkinson, J.D.; Murray, B.J.; Woodhouse, M.T.; Whale, T.F.; Baustian, K.J.; Carslaw, K.S.; Dobbie, S.; O'Sullivan, D.; Malkin, T.L. The importance of feldspar for ice nucleation by mineral dust in mixed-phase clouds. Nature 2013, 498, 355-358. [CrossRef] [PubMed]

66. Fröhlich-Nowoisky, J.; Kampf, C.J.; Weber, B.; Huffman, J.A.; Pöhlker, C.; Andreae, M.O.; Lang-Yona, N.; Burrows, S.M.; Gunthe, S.S.; Elbert, W. Bioaerosols in the Earth system: Climate, health, and ecosystem interactions. Atmos. Res. 2016, 182, 346-376. [CrossRef]

67. Bartels-Rausch, T.; Bergeron, V.; Cartwright, J.H.; Escribano, R.; Finney, J.L.; Grothe, H.; Gutiérrez, P.J.; Haapala, J.; Kuhs, W.F.; Pettersson, J.B. Ice structures, patterns, and processes: A view across the icefields. Rev. Mod. Phys. 2012, 84, 885. [CrossRef]

68. Christner, B.C.; Morris, C.E.; Foreman, C.M.; Cai, R.; Sands, D.C. Ubiquity of biological ice nucleators in snowfall. Science 2008, 319, 1214-1214. [CrossRef] [PubMed]

69. Christner, B.C.; Cai, R.; Morris, C.E.; McCarter, K.S.; Foreman, C.M.; Skidmore, M.L.; Montross, S.N.; Sands, D.C. Geographic, seasonal, and precipitation chemistry influence on the abundance and activity of biological ice nucleators in rain and snow. Proc. Natl. Acad. Sci. USA 2008, 105, 18854-18859. [CrossRef] [PubMed]

70. Zachariassen, K.E.; Kristiansen, E. Ice nucleation and antinucleation in nature. Cryobiology 2000, 41, $257-279$. [CrossRef] [PubMed]

71. Davies, P.L. Ice-binding proteins: A remarkable diversity of structures for stopping and starting ice growth. Trends Biochem. Sci. 2014, 39, 548-555. [CrossRef] [PubMed]

72. Dreischmeier, K.; Budke, C.; Wiehemeier, L.; Kottke, T.; Koop, T. Boreal pollen contain ice-nucleating as well as ice-binding "antifreeze" polysaccharides. Sci. Rep. 2017, 7, 41890. [CrossRef] [PubMed]

73. Schauperl, M.; Podewitz, M.; Waldner, B.J.; Liedl, K.R. Enthalpic and Entropic Contributions to Hydrophobicity. J. Chem. Theory Comput. 2016, 12, 4600-4610. [CrossRef] [PubMed]

74. Franzese, G.; Bianco, V.; Iskrov, S. Water at interface with proteins. Food Biophys. 2011, 6, 186-198. [CrossRef]

75. Bianco, V.; Iskrov, S.; Franzese, G. Understanding the role of hydrogen bonds in water dynamics and protein stability. J. Biol. Phys. 2012, 38, 27-48. [CrossRef] [PubMed]

76. Franzese, G.; Bianco, V. Water at biological and inorganic interfaces. Food Biophys. 2013, 8, 153-169. [CrossRef]

77. Bianco, V.; Franzese, G. Contribution of water to pressure and cold denaturation of proteins. Phys. Rev. Lett. 2015, 115, 108101. [CrossRef] [PubMed] 
78. Coluzza, I. A coarse-grained approach to protein design: Learning from design to understand folding. PLoS ONE 2011, 6, e20853. [CrossRef] [PubMed]

79. Coluzza, I. Transferable coarse-grained potential for de novo protein folding and design. PLoS ONE 2014, 9, e112852. [CrossRef] [PubMed]

80. Morawietz, T.; Singraber, A.; Dellago, C.; Behler, J. How van der Waals interactions determine the unique properties of water. Proc. Natl. Acad. Sci. USA 2016, 8368-8373. [CrossRef] [PubMed]

81. Quigley, D.; Rodger, P.M.; Freeman, C.L.; Harding, J.H.; Duffy, D.M. Metadynamics simulations of calcite crystallization on self-assembled monolayers. J. Chem. Phys. 2009, 131, 94703. [CrossRef] [PubMed]

82. Coluzza, I.; Frenkel, D. Virtual-Move Parallel Tempering. ChemPhysChem 2005, 6, 1779-1783. [CrossRef] [PubMed]

83. Bolhuis, P.G.; Dellago, C. 3 Trajectory-Based Rare Event Simulations. Rev. Comput. Chem. 2011, $27,111$.

84. Bolhuis, P.G.; Dellago, C. Practical and conceptual path sampling issues. Eur. Phys. J. Spec. Top. 2015, 224, 2409-2427. [CrossRef]

85. Baschnagel, J.; Binder, K.; Doruker, P.; Gusev, A.A.; Hahn, O.; Kremer, K.; Mattice, W.L.; Müller-Plathe, F.; Murat, M.; Paul, W. Bridging the gap between atomistic and coarse-grained models of polymers: Status and perspectives. In Viscoelasticity, Atomistic Models, Statistical Chemistry; Springer: Berlin, Germany, 2000; pp. 41-156. ISBN 978-3-540-46778-6.

86. Murat, M.; Kremer, K. From many monomers to many polymers: Soft ellipsoid model for polymer melts and mixtures. J. Chem. Phys. 1998, 108, 4340-4348. [CrossRef]

87. Potestio, R.; Peter, C.; Kremer, K. Computer simulations of soft matter: Linking the scales. Entropy 2014, 16, 4199-4245. [CrossRef]

88. Pierleoni, C.; Capone, B.; Hansen, J.-P. A soft effective segment representation of semidilute polymer solutions. J. Chem. Phys. 2007, 127, 171102. [CrossRef] [PubMed]

89. Capone, B.; Hansen, J.P.; Coluzza, I. Competing micellar and cylindrical phases in semi-dilute diblock copolymer solutions. Soft Matter 2010, 6, 6075-6078. [CrossRef]

90. Coluzza, I.; Capone, B.; Hansen, J.P. Rescaling of structural length scales for "soft effective segment" representations of polymers in good solvent. Soft Matter 2011, 7, 5255-5259. [CrossRef]

91. Maki, L.R.; Willoughby, K.J. Bacteria as biogenic sources of freezing nuclei. J. Appl. Meteorol. 1978, 17, 1049-1053. [CrossRef]

92. Diehl, K.; Quick, C.; Matthias-Maser, S.; Mitra, S.K.; Jaenicke, R. The ice nucleating ability of pollen: Part I: Laboratory studies in deposition and condensation freezing modes. Atmos. Res. 2001, 58, 75-87. [CrossRef]

93. Diehl, K.; Matthias-Maser, S.; Jaenicke, R.; Mitra, S.K. The ice nucleating ability of pollen: Part II. Laboratory studies in immersion and contact freezing modes. Atmos. Res. 2002, 61, 125-133. [CrossRef]

94. O'sullivan, D.; Murray, B.J.; Malkin, T.L.; Whale, T.F.; Umo, N.S.; Atkinson, J.D.; Price, H.C.; Baustian, K.J.; Webb, M.E. Ice nucleation by fertile soil dusts: Relative importance of mineral and biogenic components. Atmos. Chem. Phys. 2014, 14, 1853-1867. [CrossRef]

95. Schnell, R.C.; Vali, G. Biogenic ice nuclei: Part I. Terrestrial and marine sources. J. Atmos. Sci. 1976, 33, 1554-1564. [CrossRef]

96. Hallett, J. Production of secondary ice particles during the riming process. Nature 1974, 249, 26-28. [CrossRef]

97. Peckhaus, A.; Kiselev, A.; Hiron, T.; Ebert, M.; Leisner, T. A comparative study of K-rich and Na/Ca-rich feldspar ice-nucleating particles in a nanoliter droplet freezing assay. Atmos. Chem. Phys. 2016, 16, 11477-11496. [CrossRef]

98. Harrison, A.D.; Whale, T.F.; Carpenter, M.A.; Holden, M.A.; Neve, L.; O'Sullivan, D.; Vergara Temprado, J.; Murray, B.J. Not all feldspars are equal: A survey of ice nucleating properties across the feldspar group of minerals. Atmos. Chem. Phys. 2016, 16, 10927-10940. [CrossRef]

99. Sands, D.C.; Langhans, V.E.; Scharen, A.L.; De Smet, G. The association between bacteria and rain and possible resultant meteorological implications. Idojaras 1982, 86, 148-152.

100. Morris, C.E.; Georgakopoulos, D.G.; Sands, D.C. Ice nucleation active bacteria and their potential role in precipitation. J. Phys. IV Fr. 2004, 121, 87-103. [CrossRef]

101. Morris, C.E.; Sands, D.C.; Vinatzer, B.A.; Glaux, C.; Guilbaud, C.; Buffiere, A.; Yan, S.; Dominguez, H.; Thompson, B.M. The life history of the plant pathogen Pseudomonas syringae is linked to the water cycle. ISME J. 2008, 2, 321-334. [CrossRef] [PubMed] 
102. Morris, C.E.; Conen, F.; Alex Huffman, J.; Phillips, V.; Pöschl, U.; Sands, D.C. Bioprecipitation: A feedback cycle linking Earth history, ecosystem dynamics and land use through biological ice nucleators in the atmosphere. Glob. Chang. Biol. 2014, 20, 341-351. [CrossRef] [PubMed]

103. Monteil, C.L.; Bardin, M.; Morris, C.E. Features of air masses associated with the deposition of Pseudomonas syringae and Botrytis cinerea by rain and snowfall. ISME J. 2014, 8, 2290-2304. [CrossRef] [PubMed]

104. Fröhlich-Nowoisky, J.; Hill, T.C.; Pummer, B.G.; Yordanova, P.; Franc, G.D.; Pöschl, U. Ice nucleation activity in the widespread soil fungus Mortierella alpina. Biogeosciences 2015, 12, 1057. [CrossRef]

105. Pouleur, S.; Richard, C.; Martin, J.G.; Antoun, H. Ice nucleation activity in Fusarium acuminatum and Fusarium avenaceum. Appl. Environ. Microbiol. 1992, 58, 2960-2964. [PubMed]

106. Richard, C.; Martin, J.G.; Pouleur, S. Ice nucleation activity identified in some phytopathogenic Fusarium species. Phytoprotection 1996, 77, 83-92. [CrossRef]

107. O'Sullivan, D.; Murray, B.J.; Ross, J.F.; Webb, M.E. The adsorption of fungal ice-nucleating proteins on mineral dusts: A terrestrial reservoir of atmospheric ice-nucleating particles. Atmos. Chem. Phys. 2016, 16, 7879-7887.

108. Gurian-Sherman, D.; Lindow, S.E. Bacterial ice nucleation: Significance and molecular basis. FASEB J. 1993, 7, 1338-1343. [PubMed]

109. Pietsch, R.B.; David, R.F.; Marr, L.C.; Vinatzer, B.; Schmale, D.G., III. Aerosolization of Two Strains (Ice+ and Ice-) of Pseudomonas syringae in a Collison Nebulizer at Different Temperatures. Aerosol Sci. Technol. 2015, 49, 159-166. [CrossRef]

110. D'souza, N.A.; Kawarasaki, Y.; Gantz, J.D.; Lee, R.E.; Beall, B.F.N.; Shtarkman, Y.M.; Kocer, Z.A.; Rogers, S.O.; Wildschutte, H.; Bullerjahn, G.S. Diatom assemblages promote ice formation in large lakes. ISME J. 2013, 7, 1632-1640. [CrossRef] [PubMed]

111. Moffett, B.F. Fresh water ice nuclei. Fundam. Appl. Limnol. Hydrobiol. 2016, 188, 19-23. [CrossRef]

112. Pietsch, R.B.; Vinatzer, B.A.; Schmale, D.G., III. Diversity and abundance of ice nucleating strains of Pseudomonas syringae in a freshwater lake in Virginia, USA. Front. Microbiol. 2017, 8, 318. [CrossRef] [PubMed]

113. Wilson, T.W.; Ladino, L.A.; Alpert, P.A.; Breckels, M.N.; Brooks, I.M.; Browse, J.; Burrows, S.M.; Carslaw, K.S.; Huffman, J.A.; Judd, C.; et al. A marine biogenic source of atmospheric ice-nucleating particles. Nature 2015, 525, 234-238. [CrossRef] [PubMed]

114. Wright, T.P.; Hader, J.D.; McMeeking, G.R.; Petters, M.D. High relative humidity as a trigger for widespread release of ice nuclei. Aerosol Sci. Technol. 2014, 48, 1-5. [CrossRef]

115. Schnell, R.C.; Vali, G. Atmospheric ice nuclei from decomposing vegetation. Nature 1972, 236, $163-165$. [CrossRef]

116. Augustin, S.; Wex, H.; Niedermeier, D.; Pummer, B.; Grothe, H.; Hartmann, S.; Tomsche, L.; Clauss, T.; Voigtländer, J.; Ignatius, K. Immersion freezing of birch pollen washing water. Atmos. Chem. Phys. 2013, 13, 10989-11003. [CrossRef]

117. Pummer, B.G.; Budke, C.; Augustin-Bauditz, S.; Niedermeier, D.; Felgitsch, L.; Kampf, C.J.; Huber, R.G.; Liedl, K.R.; Loerting, T.; Moschen, T.; et al. Ice nucleation by water-soluble macromolecules. Atmos. Chem. Phys. 2015, 15, 4077-4091. [CrossRef]

118. Alpert, P.A.; Aller, J.Y.; Knopf, D.A. Initiation of the ice phase by marine biogenic surfaces in supersaturated gas and supercooled aqueous phases. Phys. Chem. Chem. Phys. 2011, 13, 19882-19894. [CrossRef] [PubMed]

119. Janech, M.G.; Krell, A.; Mock, T.; Kang, J.S.; Raymond, J.A. Ice-Binding Proteins from Sea Ice Diatoms (Bacillariophyceae) 1. J. Phycol. 2006, 42, 410-416. [CrossRef]

120. Knopf, D.A.; Alpert, P.A. A water activity based model of heterogeneous ice nucleation kinetics for freezing of water and aqueous solution droplets. Faraday Discuss. 2013, 165, 513-534. [CrossRef] [PubMed]

121. Behzad, H.; Gojobori, T.; Mineta, K. Challenges and opportunities of airborne metagenomics. Genome Biol. Evol. 2015, 7, 1216-1226. [CrossRef] [PubMed]

122. Goulet, F. Frost heaving of forest tree seedlings: A review. New For. 1995, 9, 67-94. [CrossRef]

123. Gu, L.; Hanson, P.J.; Post, W.M.; Kaiser, D.P.; Yang, B.; Nemani, R.; Pallardy, S.G.; Meyers, T. The 2007 eastern US spring freeze: Increased cold damage in a warming world? AIBS Bull. 2008, 58, 253-262. [CrossRef]

124. Maqbool, A.; Shafiq, S.; Lake, L. Radiant frost tolerance in pulse crops-a review. Euphytica 2010, 172, 1-12. [CrossRef] 
125. Duman, J.G.; Wisniewski, M.J. The use of antifreeze proteins for frost protection in sensitive crop plants. Environ. Exp. Bot. 2014, 106, 60-69. [CrossRef]

126. Neuner, G. Frost resistance in alpine woody plants. Front. Plant Sci. 2014, 5, 654. [CrossRef] [PubMed]

127. Lindow, S.E. The role of bacterial ice nucleation in frost injury to plants. Annu. Rev. Phytopathol. 1983, 21, 363-384. [CrossRef]

128. Bottalico, A.; Perrone, G. Toxigenic Fusarium species and mycotoxins associated with head blight in small-grain cereals in Europe. Eur. J. Plant Pathol. 2002, 108, 611-624. [CrossRef]

129. Thomashow, M.F. Plant cold acclimation: Freezing tolerance genes and regulatory mechanisms. Annu. Rev. Plant Biol. 1999, 50, 571-599. [CrossRef] [PubMed]

130. Amato, P.; Joly, M.; Schaupp, C.; Attard, E.; Möhler, O.; Morris, C.E.; Brunet, Y.; Delort, A.M. Survival and ice nucleation activity of bacteria as aerosols in a cloud simulation chamber. Atmos. Chem. Phys. 2015, 15, 6455-6465. [CrossRef]

131. Joly, M.; Attard, E.; Sancelme, M.; Deguillaume, L.; Guilbaud, C.; Morris, C.E.; Amato, P.; Delort, A.M. Ice nucleation activity of bacteria isolated from cloud water. Atmos. Environ. 2013, 70, 392-400. [CrossRef]

132. Quinn, P.K.; Collins, D.B.; Grassian, V.H.; Prather, K.A.; Bates, T.S. Chemistry and related properties of freshly emitted sea spray aerosol. Chem. Rev. 2015, 115, 4383-4399. [CrossRef] [PubMed]

133. Ladino, L.A.; Yakobi-Hancock, J.D.; Kilthau, W.P.; Mason, R.H.; Si, M.; Li, J.; Miller, L.A.; Schiller, C.L.; Huffman, J.A.; Aller, J.Y. Addressing the ice nucleating abilities of marine aerosol: A combination of deposition mode laboratory and field measurements. Atmos. Environ. 2016, 132, 1-10. [CrossRef]

134. Christner, B.C.; Mosley-Thompson, E.; Thompson, L.G.; Reeve, J.N. Isolation of bacteria and 16S rDNAs from Lake Vostok accretion ice. Environ. Microbiol. 2001, 3, 570-577. [CrossRef] [PubMed]

135. Salam, A.; Lohmann, U.; Lesins, G. Ice nucleation of ammonia gas exposed montmorillonite mineral dust particles. Atmos. Chem. Phys. 2007, 7, 3923-3931. [CrossRef]

136. Hoose, C.; Lohmann, U.; Erdin, R.; Tegen, I. The global influence of dust mineralogical composition on heterogeneous ice nucleation in mixed-phase clouds. Environ. Res. Lett. 2008, 3, 25003. [CrossRef]

137. Niedermeier, D.; Hartmann, S.; Clauss, T.; Wex, H.; Kiselev, A.; Sullivan, R.C.; DeMott, P.J.; Petters, M.D.; Reitz, P.; Schneider, J. Experimental study of the role of physicochemical surface processing on the IN ability of mineral dust particles. Atmos. Chem. Phys. 2011, 11, 11131-11144. [CrossRef]

138. Zolles, T.; Burkart, J.; Häusler, T.; Pummer, B.; Hitzenberger, R.; Grothe, H. Identification of ice nucleation active sites on feldspar dust particles. J. Phys. Chem. A 2015, 119, 2692-2700. [CrossRef] [PubMed]

139. Kanji, Z.A.; Welti, A.; Chou, C.; Stetzer, O.; Lohmann, U. Laboratory studies of immersion and deposition mode ice nucleation of ozone aged mineral dust particles. Atmos. Chem. Phys. 2013, 13, 9097-9118. [CrossRef]

140. Rudich, Y.; Donahue, N.M.; Mentel, T.F. Aging of organic aerosol: Bridging the gap between laboratory and field studies. Annu. Rev. Phys. Chem. 2007, 58, 321-352. [CrossRef] [PubMed]

141. George, I.J.; Abbatt, J.P.D. Heterogeneous oxidation of atmospheric aerosol particles by gas-phase radicals. Nat. Chem. 2010, 2, 713. [CrossRef] [PubMed]

142. Brooks, S.D.; Suter, K.; Olivarez, L. Effects of chemical aging on the ice nucleation activity of soot and polycyclic aromatic hydrocarbon aerosols. J. Phys. Chem. A 2014, 118, 10036-10047. [CrossRef] [PubMed]

143. Pummer, B.G.; Bauer, H.; Bernardi, J.; Bleicher, S.; Grothe, H. Suspendable macromolecules are responsible for ice nucleation activity of birch and conifer pollen. Atmos. Chem. Phys. 2012, 12, 2541-2550. [CrossRef]

144. Hartmann, S.; Augustin, S.; Clauss, T.; Wex, H.; Šantl-Temkiv, T.; Voigtländer, J.; Niedermeier, D.; Stratmann, F. Immersion freezing of ice nucleation active protein complexes. Atmos. Chem. Phys. 2013, 13, 5751-5766. [CrossRef]

145. Augustin-Bauditz, S.; Wex, H.; Denjean, C.; Hartmann, S.; Schneider, J.; Schmidt, S.; Ebert, M.; Stratmann, F. Laboratory-generated mixtures of mineral dust particles with biological substances: Characterization of the particle mixing state and immersion freezing behavior. Atmos. Chem. Phys. 2016, 16, 5531-5543. [CrossRef]

146. Rangel-Alvarado, R.B.; Nazarenko, Y.; Ariya, P.A. Snow-borne nanosized particles: Abundance, distribution, composition, and significance in ice nucleation processes. J. Geophys. Res. Atmos. 2015, 120. [CrossRef]

147. Kajava, A.V.; Lindow, S.E. A model of the three-dimensional structure of ice nucleation proteins. J. Mol. Biol. 1993, 232, 709-717. [CrossRef] [PubMed]

148. Govindarajan, A.G.; Lindow, S.E. Size of bacterial ice-nucleation sites measured in situ by radiation inactivation analysis. Proc. Natl. Acad. Sci. USA 1988, 85, 1334-1338. [CrossRef] [PubMed] 
149. Kozloff, L.M.; Turner, M.A.; Arellano, F.; Lute, M. Phosphatidylinositol, a phospholipid of ice-nucleating bacteria. J. Bacteriol. 1991, 173, 2053-2060. [CrossRef] [PubMed]

150. Govindarajan, A.G.; Lindow, S.E. Phospholipid requirement for expression of ice nuclei in Pseudomonas syringae and in vitro. J. Biol. Chem. 1988, 263, 9333-9338. [PubMed]

151. Sharma, V.K.; Graham, N.J. Oxidation of amino acids, peptides and proteins by ozone: A review. Ozone Sci. Eng. 2010, 32, 81-90. [CrossRef]

152. Kieft, T.L.; Ruscetti, T. Characterization of biological ice nuclei from a lichen. J. Bacteriol. 1990, 172, 3519-3523. [CrossRef] [PubMed]

153. Ofner, J.; Krüger, H.U.; Grothe, H.; Schmitt-Kopplin, P.; Whitmore, K.; Zetzsch, C. Physico-chemical characterization of SOA derived from catechol and guaiacol-a model substance for the aromatic fraction of atmospheric HULIS. Atmos. Chem. Phys. 2011, 11, 1-15. [CrossRef]

154. Adler, G.; Koop, T.; Haspel, C.; Taraniuk, I.; Moise, T.; Koren, I.; Heiblum, R.H.; Rudich, Y. Formation of highly porous aerosol particles by atmospheric freeze-drying in ice clouds. Proc. Natl. Acad. Sci. USA 2013, 110, 20414-20419. [CrossRef] [PubMed]

155. Baustian, K.J.; Wise, M.E.; Jensen, E.J.; Schill, G.P.; Freedman, M.A.; Tolbert, M.A. State transformations and ice nucleation in amorphous (semi-) solid organic aerosol. Atmos. Chem. Phys. 2013, 13, 5615. [CrossRef]

156. Möhler, O.; Benz, S.; Saathoff, H.; Schnaiter, M.; Wagner, R.; Schneider, J.; Walter, S.; Ebert, V.; Wagner, S. The effect of organic coating on the heterogeneous ice nucleation efficiency of mineral dust aerosols. Environ. Res. Lett. 2008, 3, 25007. [CrossRef]

157. Pöschl, U.; Martin, S.T.; Sinha, B.; Chen, Q.; Gunthe, S.S.; Huffman, J.A.; Borrmann, S.; Farmer, D.K.; Garland, R.M.; Helas, G. Rainforest aerosols as biogenic nuclei of clouds and precipitation in the Amazon. Science 2010, 329, 1513-1516. [CrossRef] [PubMed]

158. Zobrist, B.; Marcolli, C.; Koop, T.; Luo, B.P.; Murphy, D.M.; Lohmann, U.; Zardini, A.A.; Krieger, U.K.; Corti, T.; Cziczo, D.J. Oxalic acid as a heterogeneous ice nucleus in the upper troposphere and its indirect aerosol effect. Atmos. Chem. Phys. 2006, 6, 3115-3129. [CrossRef]

159. Shiraiwa, M.; Selzle, K.; Yang, H.; Sosedova, Y.; Ammann, M.; Pöschl, U. Multiphase chemical kinetics of the nitration of aerosolized protein by ozone and nitrogen dioxide. Environ. Sci. Technol. 2012, 46, 6672-6680. [CrossRef] [PubMed]

160. Riccobono, F.; Schobesberger, S.; Scott, C.E.; Dommen, J.; Ortega, I.K.; Rondo, L.; Almeida, J.; Amorim, A.; Bianchi, F.; Breitenlechner, M. Oxidation products of biogenic emissions contribute to nucleation of atmospheric particles. Science 2014, 344, 717-721. [CrossRef] [PubMed]

161. Ignatius, K.; Kristensen, T.B.; Järvinen, E.; Nichman, L.; Fuchs, C.; Gordon, H.; Herenz, P.; Hoyle, C.R.; Duplissy, J.; Garimella, S. Heterogeneous ice nucleation of viscous secondary organic aerosol produced from ozonolysis of $\alpha$-pinene. Atmos. Chem. Phys. 2016, 16, 6495-6509. [CrossRef]

162. Ellison, G.B.; Tuck, A.F.; Vaida, V. Atmospheric processing of organic aerosols. J. Geophys. Res. Atmos. 1999, 104, 11633-11641. [CrossRef]

163. Baltensperger, U.; Kalberer, M.; Dommen, J.; Paulsen, D.; Alfarra, M.R.; Coe, H.; Fisseha, R.; Gascho, A.; Gysel, M.; Nyeki, S. Secondary organic aerosols from anthropogenic and biogenic precursors. Faraday Discuss. 2005, 130, 265-278. [CrossRef] [PubMed]

164. Kalberer, M.; Sax, M.; Samburova, V. Molecular size evolution of oligomers in organic aerosols collected in urban atmospheres and generated in a smog chamber. Environ. Sci. Technol. 2006, 40, 5917-5922. [CrossRef] [PubMed]

165. Walser, M.L.; Park, J.; Gomez, A.L.; Russell, A.R.; Nizkorodov, S.A. Photochemical aging of secondary organic aerosol particles generated from the oxidation of d-limonene. J. Phys. Chem. A 2007, 111, 1907-1913. [CrossRef] [PubMed]

166. Tritscher, T.; Dommen, J.; DeCarlo, P.F.; Gysel, M.; Barmet, P.B.; Praplan, A.P.; Weingartner, E.; Prévôt, A.S.H.; Riipinen, I.; Donahue, N.M. Volatility and hygroscopicity of aging secondary organic aerosol in a smog chamber. Atmos. Chem. Phys. 2011, 11, 11477-11496. [CrossRef]

167. Donahue, N.M.; Henry, K.M.; Mentel, T.F.; Kiendler-Scharr, A.; Spindler, C.; Bohn, B.; Brauers, T.; Dorn, H.P.; Fuchs, H.; Tillmann, R. Aging of biogenic secondary organic aerosol via gas-phase $\mathrm{OH}$ radical reactions. Proc. Natl. Acad. Sci. USA 2012, 109, 13503-13508. [CrossRef] [PubMed] 
168. Müller, L.; Reinnig, M.C.; Naumann, K.H.; Saathoff, H.; Mentel, T.F.; Donahue, N.M.; Hoffmann, T. Formation of 3-methyl-1, 2, 3-butanetricarboxylic acid via gas phase oxidation of pinonic acid-a mass spectrometric study of SOA aging. Atmos. Chem. Phys. 2012, 12, 1483-1496. [CrossRef]

169. Koop, T.; Bookhold, J.; Shiraiwa, M.; Pöschl, U. Glass transition and phase state of organic compounds: Dependency on molecular properties and implications for secondary organic aerosols in the atmosphere. Phys. Chem. Chem. Phys. 2011, 13, 19238-19255. [CrossRef] [PubMed]

170. Cappa, C.D.; Wilson, K.R. Evolution of organic aerosol mass spectra upon heating: Implications for OA phase and partitioning behavior. Atmos. Chem. Phys. 2011, 11, 1895-1911. [CrossRef]

171. Vaden, T.D.; Imre, D.; Beránek, J.; Shrivastava, M.; Zelenyuk, A. Evaporation kinetics and phase of laboratory and ambient secondary organic aerosol. Proc. Natl. Acad. Sci. USA 2011, 108, 2190-2195. [CrossRef] [PubMed]

172. Roth, C.M.; Goss, K.U.; Schwarzenbach, R.P. Sorption of a diverse set of organic vapors to urban aerosols. Environ. Sci. Technol. 2005, 39, 6638-6643. [CrossRef] [PubMed]

173. Bones, D.L.; Reid, J.P.; Lienhard, D.M.; Krieger, U.K. Comparing the mechanism of water condensation and evaporation in glassy aerosol. Proc. Natl. Acad. Sci. USA 2012, 109, 11613-11618. [CrossRef] [PubMed]

174. Saukko, E.; Kuuluvainen, H.; Virtanen, A. A method to resolve the phase state of aerosol particles. Atmos. Meas. Tech. 2012, 5, 259-265. [CrossRef]

175. Wang, B.; Lambe, A.T.; Massoli, P.; Onasch, T.B.; Davidovits, P.; Worsnop, D.R.; Knopf, D.A. The deposition ice nucleation and immersion freezing potential of amorphous secondary organic aerosol: Pathways for ice and mixed-phase cloud formation. J. Geophys. Res. Atmos. 2012, 117. [CrossRef]

176. Grayson, J.W.; Zhang, Y.; Mutzel, A.; Renbaum-Wolff, L.; Böge, O.; Kamal, S.; Herrmann, H.; Martin, S.T.; Bertram, A.K. Effect of varying experimental conditions on the viscosity of $\alpha$-pinene derived secondary organic material. Atmos. Chem. Phys. 2016, 16, 6027-6040. [CrossRef]

177. Szmigielski, R.; Surratt, J.D.; Gómez-González, Y.; Van der Veken, P.; Kourtchev, I.; Vermeylen, R.; Blockhuys, F.; Jaoui, M.; Kleindienst, T.E.; Lewandowski, M. 3-methyl-1, 2, 3-butanetricarboxylic acid: An atmospheric tracer for terpene secondary organic aerosol. Geophys. Res. Lett. 2007, 34, 387868. [CrossRef]

178. Claeys, M.; Iinuma, Y.; Szmigielski, R.; Surratt, J.D.; Blockhuys, F.; van Alsenoy, C.; Böge, O.; Sierau, B.; Gómez-González, Y.; Vermeylen, R. Terpenylic acid and related compounds from the oxidation of $\alpha$-pinene: Implications for new particle formation and growth above forests. Environ. Sci. Technol. 2009, 43, 6976-6982. [CrossRef] [PubMed]

179. Iinuma, Y.; Keywood, M.; Gnauk, T.; Herrmann, H. Diaterebic acid acetate and diaterpenylic acid acetate: Atmospheric tracers for secondary organic aerosol formation from 1, 8-cineole oxidation. Environ. Sci. Technol. 2008, 43, 280-285. [CrossRef]

180. Iinuma, Y.; Engling, G.; Puxbaum, H.; Herrmann, H. A highly resolved anion-exchange chromatographic method for determination of saccharidic tracers for biomass combustion and primary bio-particles in atmospheric aerosol. Atmos. Environ. 2009, 43, 1367-1371. [CrossRef]

181. Mutzel, A.; Rodigast, M.; Iinuma, Y.; Böge, O.; Herrmann, H. Monoterpene SOA-contribution of first-generation oxidation products to formation and chemical composition. Atmos. Environ. 2016, 130, 136-144. [CrossRef]

182. Christoffersen, T.S.; Hjorth, J.; Horie, O.; Jensen, N.R.; Kotzias, D.; Molander, L.L.; Neeb, P.; Ruppert, L.; Winterhalter, R.; Virkkula, A. cis-Pinic acid, a possible precursor for organic aerosol formation from ozonolysis of $\alpha$-pinene. Atmos. Environ. 1998, 32, 1657-1661. [CrossRef]

183. Iinuma, Y.; Brüggemann, E.; Gnauk, T.; Müller, K.; Andreae, M.O.; Helas, G.; Parmar, R.; Herrmann, H. Source characterization of biomass burning particles: The combustion of selected European conifers, African hardwood, savanna grass, and German and Indonesian peat. J. Geophys. Res. Atmos. 2007, 112, 08209. [CrossRef]

184. Hoffmann, D.; Tilgner, A.; Iinuma, Y.; Herrmann, H. Atmospheric stability of levoglucosan: A detailed laboratory and modeling study. Environ. Sci. Technol. 2009, 44, 694-699. [CrossRef] [PubMed]

185. Cziczo, D.J.; Ladino, L.; Boose, Y.; Kanji, Z.A.; Kupiszewski, P.; Lance, S.; Mertes, S.; Wex, H. Measurements of Ice Nucleating Particles and Ice Residuals. Meteorol. Monogr. 2017, 58, 8.1-8.13. [CrossRef]

186. Field, P.R.; Lawson, R.P.; Brown, P.R.A.; Lloyd, G.; Westbrook, C.; Moisseev, D.; Miltenberger, A.; Nenes, A.; Blyth, A.; Choularton, T. Secondary Ice Production: Current State of the Science and Recommendations for the Future. Meteorol. Monogr. 2017, 58, 7.1-7.20. [CrossRef] 
187. Eidhammer, T.; DeMott, P.J.; Prenni, A.J.; Petters, M.D.; Twohy, C.H.; Rogers, D.C.; Stith, J.; Heymsfield, A.; Wang, Z.; Pratt, K.A. Ice initiation by aerosol particles: Measured and predicted ice nuclei concentrations versus measured ice crystal concentrations in an orographic wave cloud. J. Atmos. Sci. 2010, 67, 2417-2436. [CrossRef]

188. Field, P.R.; Heymsfield, A.J.; Shipway, B.J.; DeMott, P.J.; Pratt, K.A.; Rogers, D.C.; Stith, J.; Prather, K.A. Ice in clouds experiment-layer clouds. Part II: Testing characteristics of heterogeneous ice formation in lee wave clouds. J. Atmos. Sci. 2012, 69, 1066-1079. [CrossRef]

189. Heymsfield, A.; Willis, P. Cloud conditions favoring secondary ice particle production in tropical maritime convection. J. Atmos. Sci. 2014, 71, 4500-4526. [CrossRef]

190. Heymsfield, A.J.; Field, P.R.; Bailey, M.; Rogers, D.; Stith, J.; Twohy, C.; Wang, Z.; Haimov, S. Ice in clouds experiment-Layer clouds. Part I: Ice growth rates derived from lenticular wave cloud penetrations. J. Atmos. Sci. 2011, 68, 2628-2654. [CrossRef]

191. Lasher-Trapp, S.; Leon, D.C.; DeMott, P.J.; Villanueva-Birriel, C.M.; Johnson, A.V.; Moser, D.H.; Tully, C.S.; $\mathrm{Wu}, \mathrm{W}$. A Multisensor Investigation of Rime Splintering in Tropical Maritime Cumuli. J. Atmos. Sci. 2016, 73, 2547-2564. [CrossRef]

192. Neely, R.; Blyth, A.; Bennett, L.; Dufton, D.; Cui, Z.; McQuaid, J.; Price, H.; Murray, B.; Huang, Y. Dual-Polarised Doppler X-band Radar Observations of Mixed Phased Clouds from the UK's Ice in Clouds Experiment-Dust (ICE-D). In Proceedings of the EGU General Assembly 2016, Vienna, Austria, 17-22 April 2016; Volume 18, p. 3084.

193. Pratt, K.A.; DeMott, P.J.; French, J.R.; Wang, Z.; Westphal, D.L.; Heymsfield, A.J.; Twohy, C.H.; Prenni, A.J.; Prather, K.A. In situ detection of biological particles in cloud ice-crystals. Nat. Geosci. 2009, 2, 398-401. [CrossRef]

194. Prenni, A.J.; Petters, M.D.; Kreidenweis, S.M.; Heald, C.L.; Martin, S.T.; Artaxo, P.; Garland, R.M.; Wollny, A.G.; Pöschl, U. Relative roles of biogenic emissions and Saharan dust as ice nuclei in the Amazon basin. Nat. Geosci. 2009, 2, 402-405. [CrossRef]

195. Meyers, M.P.; DeMott, P.J.; Cotton, W.R. New primary ice-nucleation parameterizations in an explicit cloud model. J. Appl. Meteorol. 1992, 31, 708-721. [CrossRef]

196. Fan, J.; Leung, L.R.; DeMott, P.J.; Comstock, J.M.; Singh, B.; Rosenfeld, D.; Tomlinson, J.M.; White, A.; Prather, K.A.; Minnis, P. Aerosol impacts on California winter clouds and precipitation during CalWater 2011: Local pollution versus long-range transported dust. Atmos. Chem. Phys. 2014, 14, 81-101. [CrossRef]

197. Thompson, G.; Eidhammer, T. A study of aerosol impacts on clouds and precipitation development in a large winter cyclone. J. Atmos. Sci. 2014, 71, 3636-3658. [CrossRef]

198. Vali, G. Freezing nucleus content of hail and rain in Alberta. J. Appl. Meteorol. 1971, 10, 73-78. [CrossRef]

199. Stopelli, E.; Conen, F.; Morris, C.E.; Herrmann, E.; Bukowiecki, N.; Alewell, C. Ice nucleation active particles are efficiently removed by precipitating clouds. Sci. Rep. 2015, 5, 16433. [CrossRef] [PubMed]

200. Creamean, J.M.; Lee, C.; Hill, T.C.; Ault, A.P.; DeMott, P.J.; White, A.B.; Ralph, F.M.; Prather, K.A. Chemical properties of insoluble precipitation residue particles. J. Aerosol Sci. 2014, 76, 13-27. [CrossRef]

201. Petters, M.D.; Wright, T.P. Revisiting ice nucleation from precipitation samples. Geophys. Res. Lett. 2015, 42, 8758-8766. [CrossRef]

202. DeMott, P.J.; Cziczo, D.J.; Prenni, A.J.; Murphy, D.M.; Kreidenweis, S.M.; Thomson, D.S.; Borys, R.; Rogers, D.C. Measurements of the concentration and composition of nuclei for cirrus formation. Proc. Natl. Acad. Sci. USA 2003, 100, 14655-14660. [CrossRef] [PubMed]

203. Creamean, J.M.; Suski, K.J.; Rosenfeld, D.; Cazorla, A.; DeMott, P.J.; Sullivan, R.C.; White, A.B.; Ralph, F.M.; Minnis, P.; Comstock, J.M. Dust and biological aerosols from the Sahara and Asia influence precipitation in the western US. Science 2013, 339, 1572-1578. [CrossRef] [PubMed]

204. Noone, K.J.; Ogren, J.A.; Heintzenberg, J.; Charlson, R.J.; Covert, D.S. Design and calibration of a counterflow virtual impactor for sampling of atmospheric fog and cloud droplets. Aerosol Sci. Technol. 1988, 8, 235-244. [CrossRef]

205. Hiranuma, N.; Möhler, O.; Kulkarni, G.; Schnaiter, M.; Vogt, S.; Vochezer, P.; Järvinen, E.; Wagner, R.; Bell, D.M.; Wilson, J.; et al. Development and characterization of an ice-selecting pumped counterflow virtual impactor (IS-PCVI) to study ice crystal residuals. Atmos. Meas. Tech. 2016, 9, 3817-3836. [CrossRef]

206. Mossop, S.C. Concentrations of ice crystals in clouds. Bull. Am. Meteorol. Soc. 1970, 51, 474-479. [CrossRef] 
207. Mossop, S.C.; Ono, A.; Wishart, E.R. Ice particles in maritime clouds near Tasmania. Q. J. R. Meteorol. Soc. 1970, 96, 487-508. [CrossRef]

208. Hallett, J.; Sax, R.I.; Lamb, D.; Murty, A.S. Aircraft measurements of ice in Florida cumuli. Q. J. R. Meteorol. Soc. 1978, 104, 631-651. [CrossRef]

209. Hobbs, P.V.; Rangno, A.L. Ice particle concentrations in clouds. J. Atmos. Sci. 1985, 42, 2523-2549. [CrossRef]

210. Hobbs, P.V.; Rangno, A.L. Rapid development of high ice particle concentrations in small polar maritime cumuliform clouds. J. Atmos. Sci. 1990, 47, 2710-2722. [CrossRef]

211. Rangno, A.L.; Hobbs, P.V. Ice particle concentrations and precipitation development in small polar maritime cumuliform clouds. Q. J. R. Meteorol. Soc. 1991, 117, 207-241. [CrossRef]

212. Rosinski, J.; Morgan, G. Cloud condensation nuclei as a source of ice-forming nuclei in clouds. J. Aerosol Sci. 1991, 22, 123-133. [CrossRef]

213. Santachiara, G.; Belosi, F. Does the Homogeneous Ice Nucleation Initiate in the Bulk Volume or at the Surface of Super-Cooled Water Droplets? A Review. Atmos. Clim. Sci. 2014, 4, 653. [CrossRef]

214. Griggs, D.J.; Choularton, T.W. Freezing modes of riming droplets with application to ice splinter production. Q. J. R. Meteorol. Soc. 1983, 109, 243-253. [CrossRef]

215. Takahashi, T.; Nagao, Y.; Kushiyama, Y. Possible high ice particle production during graupel-graupel collisions. J. Atmos. Sci. 1995, 52, 4523-4527. [CrossRef]

216. Oraltay, R.G.; Hallett, J. Evaporation and melting of ice crystals: A laboratory study. Atmos. Res. 1989, 24, 169-189. [CrossRef]

217. Conen, F.; Rodríguez, S.; Hülin, C.; Henne, S.; Herrmann, E.; Bukowiecki, N.; Alewell, C. Atmospheric ice nuclei at the high-altitude observatory Jungfraujoch, Switzerland. Tellus B Chem. Phys. Meteorol. 2015, 67, 25014. [CrossRef]

218. Chou, C.; Stetzer, O.; Weingartner, E.; Jurányi, Z.; Kanji, Z.A.; Lohmann, U. Ice nuclei properties within a Saharan dust event at the Jungfraujoch in the Swiss Alps. Atmos. Chem. Phys. 2011, 11, 4725-4738. [CrossRef]

219. Mertes, S.; Verheggen, B.; Walter, S.; Connolly, P.; Ebert, M.; Schneider, J.; Bower, K.N.; Cozic, J.; Weinbruch, S.; Baltensperger, U. Counterflow virtual impactor based collection of small ice particles in mixed-phase clouds for the physico-chemical characterization of tropospheric ice nuclei: Sampler description and first case study. Aerosol Sci. Technol. 2007, 41, 848-864. [CrossRef]

220. Richardson, M.S.; DeMott, P.J.; Kreidenweis, S.M.; Cziczo, D.J.; Dunlea, E.J.; Jimenez, J.L.; Thomson, D.S.; Ashbaugh, L.L.; Borys, R.D.; Westphal, D.L. Measurements of heterogeneous ice nuclei in the western United States in springtime and their relation to aerosol characteristics. J. Geophys. Res. Atmos. 2007, 112. [CrossRef]

221. Conen, F.; Morris, C.E.; Leifeld, J.; Yakutin, M.V.; Alewell, C. Biological residues define the ice nucleation properties of soil dust. Atmos. Chem. Phys. 2011, 11, 9643-9648. [CrossRef]

222. Tobo, Y.; DeMott, P.J.; Hill, T.C.J.; Prenni, A.J.; Swoboda-Colberg, N.G.; Franc, G.D.; Kreidenweis, S.M. Organic matter matters for ice nuclei of agricultural soil origin. Atmos. Chem. Phys. 2014, 14, 8521-8531. [CrossRef]

223. Murray, B.J.; O'sullivan, D.; Atkinson, J.D.; Webb, M.E. Ice nucleation by particles immersed in supercooled cloud droplets. Chem. Soc. Rev. 2012, 41, 6519-6554. [CrossRef] [PubMed]

224. Fletcher, N.H.; Squires, P. The Physics of Rainclouds: With an Introductory Chapter by P. Squires; Cambridge University Press: London, UK, 1962; Volume 3, pp. 154-196, ISBN-13: 9787100822300.

225. Cooper, W.A. Ice Initiation in Natural Clouds. Meteorol. Monogr. 1986, 43, 29-32. [CrossRef]

226. Niemand, M.; Möhler, O.; Vogel, B.; Vogel, H.; Hoose, C.; Connolly, P.; Klein, H.; Bingemer, H.; DeMott, P.; Skrotzki, J. A particle-surface-area-based parameterization of immersion freezing on desert dust particles. J. Atmos. Sci. 2012, 69, 3077-3092. [CrossRef]

227. Marcolli, C.; Gedamke, S.; Peter, T.; Zobrist, B. Efficiency of immersion mode ice nucleation on surrogates of mineral dust. Atmos. Chem. Phys. 2007, 7, 5081-5091. [CrossRef]

228. Broadley, S.L.; Murray, B.J.; Herbert, R.J.; Atkinson, J.D.; Dobbie, S.; Malkin, T.L.; Condliffe, E.; Neve, L. Immersion mode heterogeneous ice nucleation by an illite rich powder representative of atmospheric mineral dust. Atmos. Chem. Phys. 2012, 12, 287-307. [CrossRef]

229. Tobo, Y.; Prenni, A.J.; DeMott, P.J.; Huffman, J.A.; McCluskey, C.S.; Tian, G.; Pöhlker, C.; Pöschl, U.; Kreidenweis, S.M. Biological aerosol particles as a key determinant of ice nuclei populations in a forest ecosystem. J. Geophys. Res. Atmos. 2013, 118. [CrossRef] 
230. Hiranuma, N.; Augustin-Bauditz, S.; Bingemer, H.; Budke, C.; Curtius, J.; Danielczok, A.; Diehl, K.; Dreischmeier, K.; Ebert, M.; Frank, F. A comprehensive laboratory study on the immersion freezing behavior of illite NX particles: A comparison of 17 ice nucleation measurement techniques. Atmos. Chem. Phys. 2015, 15, 2489-2518. [CrossRef]

231. Wex, H.; Augustin-Bauditz, S.; Boose, Y.; Budke, C.; Curtius, J.; Diehl, K.; Dreyer, A.; Frank, F.; Hartmann, S.; Hiranuma, N. Intercomparing different devices for the investigation of ice nucleating particles using Snomax®as test substance. Atmos. Chem. Phys. 2015, 15, 1463-1485. [CrossRef]

232. Grawe, S.; Augustin-Bauditz, S.; Hartmann, S.; Hellner, L.; Pettersson, J.B.; Prager, A.; Stratmann, F.; Wex, H. The immersion freezing behavior of ash particles from wood and brown coal burning. Atmos. Chem. Phys. 2016, 16, 13911-13928. [CrossRef]

233. Reddington, C.L.; Carslaw, K.S.; Stier, P.; Schutgens, N.; Coe, H.; Liu, D.; Allan, J.; Browse, J.; Pringle, K.J.; Lee, L.A.; et al. The Global Aerosol Synthesis and Science Project (GASSP): Measurements and modelling to reduce uncertainty. Bull. Am. Meteorol. Soc. 2017. [CrossRef]

234. Seinfeld, J.H.; Bretherton, C.; Carslaw, K.S.; Coe, H.; DeMott, P.J.; Dunlea, E.J.; Feingold, G.; Ghan, S.; Guenther, A.B.; Kahn, R. Improving our fundamental understanding of the role of aerosol- cloud interactions in the climate system. Proc. Natl. Acad. Sci. USA 2016, 113, 5781-5790. [CrossRef] [PubMed]

(C) 2017 by the authors. Licensee MDPI, Basel, Switzerland. This article is an open access article distributed under the terms and conditions of the Creative Commons Attribution (CC BY) license (http://creativecommons.org/licenses/by/4.0/). 